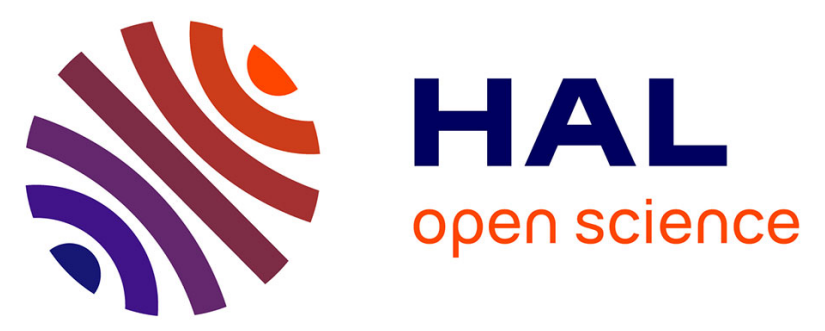

\title{
Natural and anthropogenic dynamics of the coastal environment in northwestern Corsica (western Mediterranean) over the past six millennia
}

Federico Di Rita, Matthieu Ghilardi, Nathalie Fagel, Matteo Vacchi, François

Warichet, Doriane Delanghe, Jean Sicurani, Lauriane Martinet, Sébastien

Robresco

\section{To cite this version:}

Federico Di Rita, Matthieu Ghilardi, Nathalie Fagel, Matteo Vacchi, François Warichet, et al.. Natural and anthropogenic dynamics of the coastal environment in northwestern Corsica (western Mediterranean) over the past six millennia. Quaternary Science Reviews, 2022, 278, pp.107372. 10.1016/j.quascirev.2022.107372 . hal-03542871v2

\section{HAL Id: hal-03542871 \\ https://hal.science/hal-03542871v2}

Submitted on 26 Jan 2022

HAL is a multi-disciplinary open access archive for the deposit and dissemination of scientific research documents, whether they are published or not. The documents may come from teaching and research institutions in France or abroad, or from public or private research centers.
L'archive ouverte pluridisciplinaire HAL, est destinée au dépôt et à la diffusion de documents scientifiques de niveau recherche, publiés ou non, émanant des établissements d'enseignement et de recherche français ou étrangers, des laboratoires publics ou privés.

\section{(ㅇ)(1) $\$$}

Distributed under a Creative Commons Attribution - NonCommercial - NoDerivatives 44.0 


\title{
Natural and anthropogenic dynamics of the coastal environment in northwestern Corsica (western Mediterranean) over the past six millennia
}

\author{
Federico Di Rita ${ }^{\text {a, * }}$, Matthieu Ghilardi ${ }^{b}$, Nathalie Fagel ${ }^{c}$, Matteo Vacchi ${ }^{\mathrm{d}}$, \\ François Warichet ${ }^{c}$, Doriane Delanghe ${ }^{b}$, Jean Sicurani ${ }^{e}$, Lauriane Martinet ${ }^{\mathrm{f}}$, \\ Sébastien Robresco ${ }^{\mathrm{g}}$ \\ a Sapienza University of Rome, Department of Environmental Biology, Italy \\ ${ }^{\mathrm{b}}$ CEREGE (CNRS UMR 7330-AMU-IRD-College de France-INRAE), Europôle de L'Arbois BP 80 13545, Aix-en-Provence CEDEX, 04, France \\ ${ }^{\mathrm{C}}$ AGEs, Département de Géologie, Université de Liège, 4000, Liège, Belgium \\ d Dipartimento di Scienze Della Terra, University of Pisa, Via Santa Maria 53, Pisa, Italy \\ e Association pour La Recherche Préhistorique et Protohistorique en Corse, Moncale, Corsica, France \\ ${ }^{\mathrm{f}}$ CEPAM, CNRS UMR 7264-University of Nice Sophia Antipolis, Pôle Universitaire Saint Jean D'Angély, Nice, France \\ g SIGOSPHERE, 69380, Chazay D'Azergues, France
}

\section{A R T I C L E I N F O}

\section{Article history:}

Received 31 July 2021

Received in revised form

21 December 2021

Accepted 3 January 2022

Available online $\mathrm{xxx}$

Handling Editor: Yan Zhao

\section{Keywords:}

Corsica

Pollen

Palaeoenvironments

Isotope geochemistry

Geoarchaeology

Western Mediterranean

Holocene

\begin{abstract}
A B S T R A C T
The present paper provides new insights into the climatic and anthropic factors that influenced a 6000year coastal evolution in northwestern Corsica, the third largest island of the western Mediterranean. Pollen, microcharcoal, sedimentary and geochemical analyses were carried out on a core drilled in the Crovani coastal wetland to reconstruct the regional drivers of landscape change. We show that anthropogenic and climate-induced fires favoured the development of Mediterranean maquis, dominated by Erica and Quercus ilex, from ca. 6000 to 3350 cal. BP. A change in arboreal vegetation triggered a short but intense sediment input in the Crovani pond between ca. 3350 and 3200 cal. BP. This is consistent with a coeval process of runoff recorded in several coastal sites of western Corsica and related to an arid climate change occurred in many sites of the western Mediterranean around 3200 years ago. We provide evidence of agriculture during the Late Neolithic from ca. $3900 \mathrm{BC}$, which is much earlier than any archaeological evidence previously available in this area of Corsica, followed by a progressive decline of arable farming practices. Human impact has been responsible for a degradation of the maquis only from approximately $3000 \mathrm{cal}$. BP, and it intensified in Roman times, when the area experienced the first phase of galena exploitation from the Argentella mines. Over the last 500 years, the present work evidences a major development of Castanea related to cultivation during the Genoese administration of Corsica. Our findings suggest that solar activity and the North Atlantic Oscillation had an influence on centennial-scale forest cover variations during the last 6000 years.
\end{abstract}

(C) 2022 Elsevier Ltd. All rights reserved.

\section{Introduction}

The island of Corsica hosts the largest number of coastal wetlands among the Mediterranean islands (Ghilardi, 2020, 2021). Most of them formed after the Mid-Holocene sea-level stabilization that occurred in the Mediterranean Basin between 7000 and 6000 cal. BP (Vacchi et al., 2016, 2018). Amongst the 200 coastal

\footnotetext{
* Corresponding author.

E-mail address: federico.dirita@uniroma1.it (F. Di Rita).
}

wetlands of the island, brackish lagoons and coastal ponds are the most common geomorphological features (Ghilardi, 2020).

The high potential of pollen analysis to trace the main changes in the coastal landscape of the island was first highlighted by the remarkable palynological work of Maurice Reille (Reille, 1984, 1991; 1992a). However, these pollen data were not provided with a robust chronology and did not include the analysis of Non-Pollen Palynomorphs (NPPs) and other palaeoenvironmental proxies from the same core. 
In the last few years, several Corsican wetlands situated at a short distance of the sea were the subject of multiproxy geoarchaeological research on the environmental impact of human activities, especially in Prehistoric and Protohistoric times (Early Neolithic to Final Bronze Age, ca. 7500 BP to 2800 BP) (Currás et al., 2017; Ghilardi et al., 2017a; Revelles et al., 2019; Vella et al., 2019, Fig. 1). The study of different palaeoecological proxies, such as ostracods, molluscs, and pollen, combined with the chronostratigraphy of sediments, has shown the interest of reconstructing both the paleogeography and the history of the vegetation of coastal Corsica starting from the ancient Neolithic (Cardial culture, starting from $7500 \pm 200$ cal. BP; D'Anna et al., 2001; Lugliè, 2018).
The information of palaeoenvironmental records from Corsica is paramount for detailed reconstructions of both land-use patterns and centennial-scale climate changes in the Mediterranean Basin. Indeed, the island was a crossroad for many European and North African populations in the conquest of the Mediterranean and occupies a strategic geographical location, potentially sensitive to both North Atlantic climate patterns and north African atmospheric drivers (Sabatier et al., 2020).

The aim of this paper is to outline the landscape evolution in northwestern coastal Corsica over the last six millennia, taking advantage of the recent progress in palaeoenvironmental reconstructions (Henry ed., 2020), chronological models (Reimer
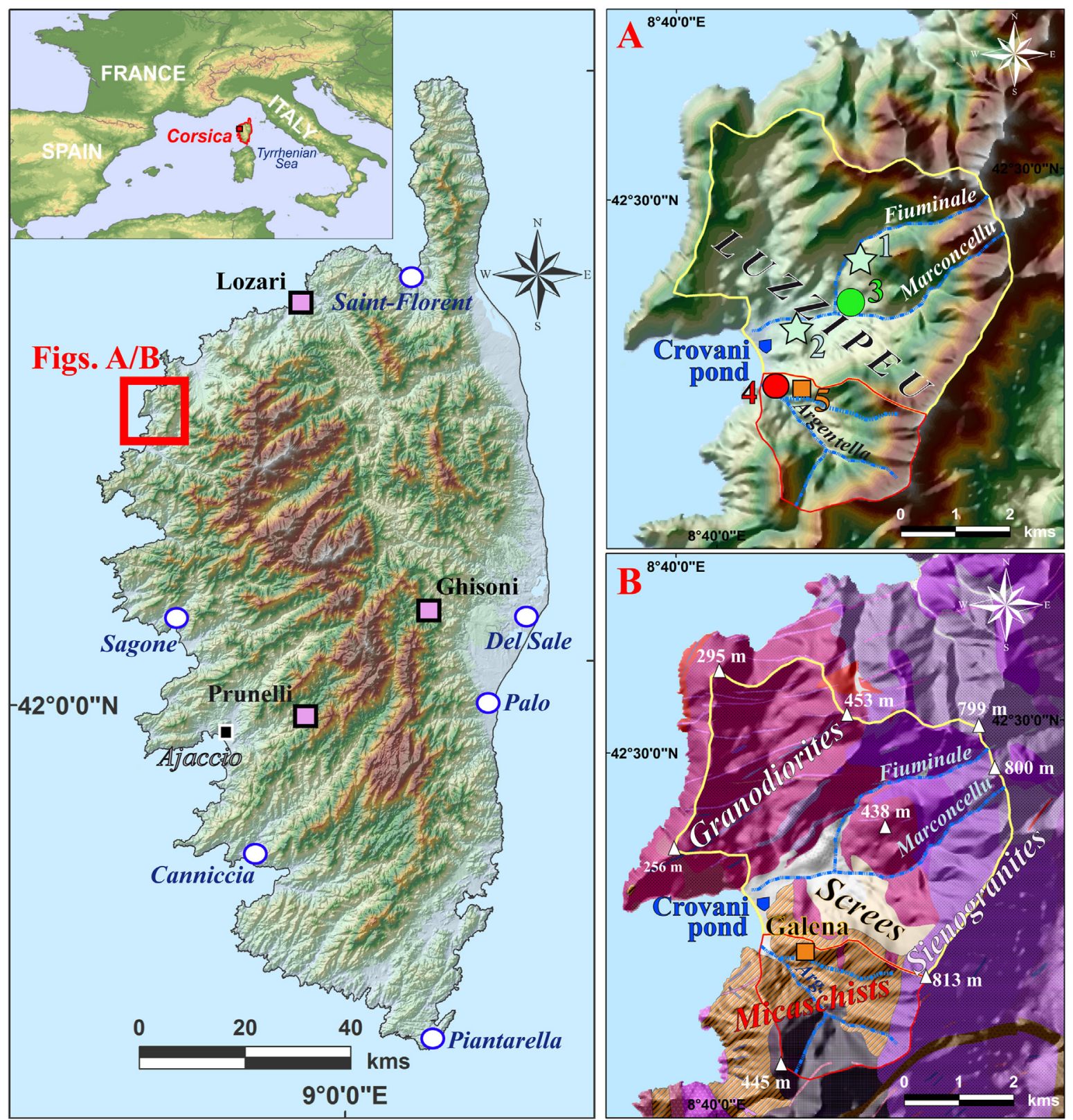

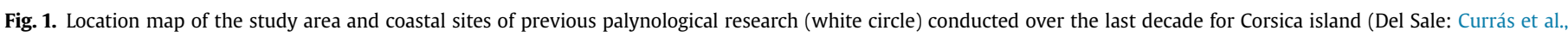

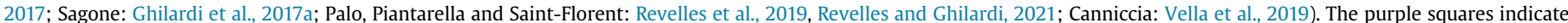

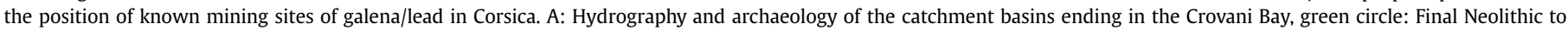

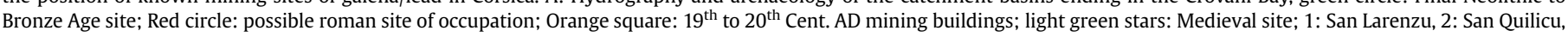

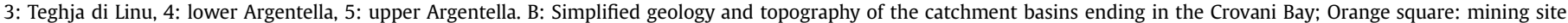

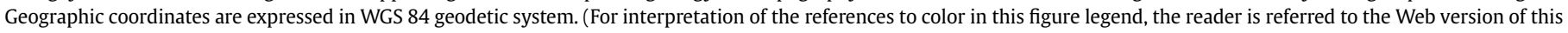
article.) 
et al., 2020), and new insights into the centennial-scale patterns of atmospheric circulation during the Middle and Late Holocene (Franke et al., 2017; Di Rita et al., 2018a; Sabatier et al., 2020).

Our new palynological and stratigraphical data are addressed to contribute to prominent unsolved questions about times and drivers of vegetational change in Corsica, with a special focus on the replacement of Erica shrublands with Quercus ilex woody formations during the Middle Holocene. A second key topic is the origin and development of land use practices in northwestern Corsica. In Neolithic times, there is sparse archaeological evidence for cereal cultivation and pastoral activities along the coasts of Corsica. Cereal cultivation was revealed by pollen analyses only in the eastern plain of Corsica and in the Saint Florent and Bonifacio-Piantarella areas (Currás et al., 2017; Revelles et al., 2019), while the osteological identification of mammals buried in sheltered caves from southern and northern Corsica provided evidence about the development of stockbreeding (Vigne, 1984, 1987).

A third unsolved question is related to the controversial role of climate changes in modifying the vegetational landscape of Corsica. While at millennial time scale the influence of climate changes on the vegetation and fires has been clearly recognized (Reille, 1992a; Leys et al., 2013; Revelles et al., 2019; Lestienne et al., 2020a, b), the role of rapid climate changes (RCC) has been seldom evoked in the regional palaeobotanical narrative. The apparent lack of vegetation responses to centennial climate changes was attributed to either the overshadowing effect produced by local resilient shrublands (Revelles et al., 2019) or the geographical position of Corsica, located in a possible climate-insensitive transitional area between the central and western Mediterranean (Di Rita and Magri, 2019; Di Rita et al., 2022), two regions where RCC often produced contrasting moisture changes (Di Rita et al., 2018a).

New detailed palaeoenvironmental data from Corsica are thus needed to disentangle these questions, which are relevant for a better understanding of the natural and anthropogenic landscape changes in the Mediterranean during the Holocene.

\section{Study area}

\subsection{Present day landscape and vegetation}

The Crovani pond is located in NW Corsica, in the westernmost part of a $\sim 1 \mathrm{~km}^{2}$ coastal plain (Fig. 1A). The plain collects the waters from two catchment basins with intermittent flow: the ArgentellaCardiccia streams (catchment basin $\sim 6 \mathrm{~km}^{2}$ ), incising metamorphic rocks (shales and mica schists) and syenogranite, and the Marconcellu-Fiuminale streams (total catchment area: ca. $23 \mathrm{~km}^{2}$ ), draining granodiorites, syenogranite, and Pliocene to Pleistocene screes in the lowermost river course (Fig. 1B).

Corsica has a typical Mediterranean climate highly influenced by its relief topography. The mean annual temperature on the whole Island ranges between $14.5{ }^{\circ} \mathrm{C}$ and $16.5^{\circ} \mathrm{C}$ and the mean annual precipitation is $890 \mathrm{~mm}$ per year. On the coastal area, mean annual temperature is higher $\left(17{ }^{\circ} \mathrm{C}\right)$ and freezing temperatures during the year are very seldom reported (Vella et al., 2019).

The Crovani wetland covers an area of $\sim 0.3 \mathrm{~km}^{2}$ behind a thick coastal barrier $\leq 5.30 \mathrm{~m}$ above the mean sea level (amsl), made up of large well-rounded pebbles and cobbles (Fig. 2). The pond, which is at $0.75 \mathrm{~m}$ amsl in the winter, is seasonal dry in the summer and has no direct link to the sea.

The surrounding wetland is a protected area, being included in the ZNIEFF (Zone naturelle d'intérêt écologique, faunistique et floristique) n. 940004139 'Etang et zones humide de Crovani' with the aim of preserving the following angiosperm species: Euphorbia peplis L., Polygonum scoparium Req. ex Loisel., Ranunculus ophioglossifolius Vill., Staphisagria picta (Willd.) Jabbour, Tamarix africana Poir., and
Vitex agnus-castus L. The pond is surrounded by a belt of T. africana and is characterized by a wet meadow covered by palustrine species dominated by Bolboschoenus maritimus (L.) Palla, Juncus acutus L. and Juncus maritimus Lam. The coastal bar is occupied by a population of Pistacia lentiscus L. and, on the top of the beach, by one of the most important Corsican populations of Vitex agnuscastus (https://inpn.mnhn.fr/zone/znieff/940004139). In spring, the very rare $S$. picta grows among the pebbles (Jeanmonod and Schlüssel, 2006). The woody vegetation of the site consists of a degraded maquis with Erica arborea L., Arbutus unedo L., Pistacia lentiscus L., Phillyrea angustifolia L. and sparse Quercus ilex L. (Reille, 1992a).

\subsection{Local archaeology and history of the human occupation}

The first evidence of human settlement in Corsica dates back to the Mesolithic (Lugliè, 2018). Abundant archaeological material allows to reconstruct the Neolithic settling history of the island (Lugliè, 2018; Revelles et al., 2019). In northern Corsica a rich archaeological background is found in a Mesolithic to Early Neolithic occupation in the Nebbiu area, at the Saint-Florent/ Patrimonio sites (Revelles et al., 2019). In the Balagne area, an important human occupation in a coastal context is attested by the Early Neolithic site (Cardial culture) of La Petra, situated on a peninsula north of the modern town of L'Île Rousse (Weiss, 2010).

In the Luzzipeu sector, situated in the southern part of the Balagne micro region, where the Crovani pond is located (Fig. 1A), despite the paucity of recognized prehistoric settlements and uncovered archaeological material, there is evidence of occupation during the Final Neolithic (starting from ca. 2800 cal. BC) at Teghja di Linu (Fig. 1A). The last site consists in a small village composed of huts, located at an elevation of $\sim 40 \mathrm{~m}$ amsl at $\sim 1.5 \mathrm{~km}$ distance from the Crovani pond, where lithics were discovered together with a menhir statue (Sicurani, 2008; Sicurani and Martinet, 2019; Ghilardi, 2020). Possible evidence of occupation during Late Neolithic times was hypothesized, but the lithics uncovered are still under investigation (Sicurani and Martinet, 2019). Due to the presence of acidic soils, derived from the erosion of the granitic bedrock, preservation of biological remains and archaeological material in this stratigraphical context is difficult, so that there is no organic material left in the archaeological layers that may help to evaluate the type of activities developed at the Teghja di Linu site. Excavations conducted over the last two decades have revealed the existence of a habitat composed of several circular large structures, delimited by tremendous rounded granitic boulders.

Protohistoric settlements are hardly documented in the Luzzipeu lowlands. Bronze Age sites are situated more inland, generally on top of hills (Peche-Quilichini, 2011). Iron Age and Roman times are poorly documented, but archaeological surveys have revealed the presence of tegulae within the mining complex of the Argentella, in use in the $19^{\text {th }}$ to $20^{\text {th }}$ century AD, indicating a first phase of galena exploitation (Leleu, 2021). This sparse human occupation from the Bronze Age to Roman times radically contrasts with the Medieval archaeological remains attested at San Larenzu and San Quilicu (Fig. 1A). Both are Romanic churches dated from the $11^{\text {th }}$ century $A D$ and nowadays almost disappeared due to their gradual destruction. From the Genovese administration to the French administration, the region was attractive for the exploitation of natural resources, especially galena minerals. Evidence for mining from the $16^{\text {th }}$ to the early $20^{\text {th }}$ centuries has been recorded (Leleu, 2021 ) but its impact in terms of landscape changes has never been investigated. 

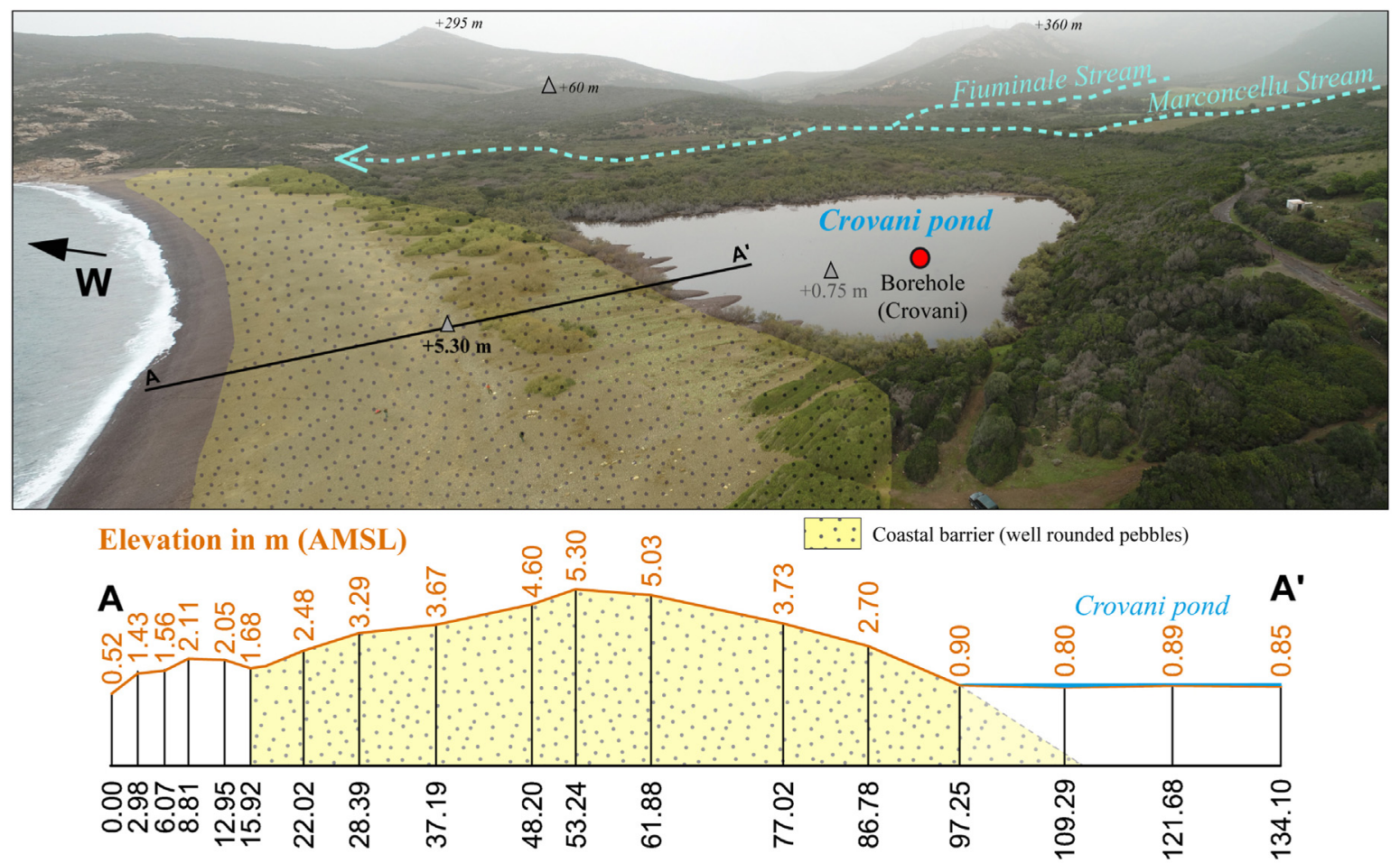

\section{Cumulated distances in $\mathbf{m}$}

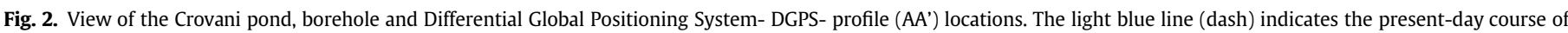
the rivers. (For interpretation of the references to color in this figure legend, the reader is referred to the Web version of this article.)

\section{Materials and methods}

In this paragraph we present a synthetic version of materials analysed and techniques we used. For a more exhaustive explanation of the methodology applied in this research, we refer to information reported in the Supplementary data.

The analyses presented in this study were carried out on a $6.25 \mathrm{~m}$ long sediment sequence, which was collected with a $50-\mathrm{mm}$ vibracore (COBRA TT equipment - Atlas Copco) in the central part of the Crovani pond in August 2018 (Fig. 2).

The chronostratigraphy of the core was established using a series of 14 AMS radiocarbon determinations made in the Poznan and Gliwice (Poland) Radiocarbon Dating Laboratories (Table 1). The Bayesian age-depth model (Fig. 3) was constructed using the software Bacon version 2.5.5 (Blaauw and Christen, 2011) with dates calibrated using the IntCal20 curve (Reimer et al., 2020).
Loss-on-ignition (LOI) measurements were performed on sediment samples of approximately $1 \mathrm{~g}$ taken at $10 \mathrm{~cm}$ intervals throughout the sequence, following the standard procedures published in Dean (1974) and Bengtsson and Enell (1986). (Fig. 4).

Samples used for LOI measurements were also analysed for granulometry. The grain-size distribution of the fine fraction $(<2 \mathrm{~mm})$ was measured by laser diffraction granulometry at CEREGE.

A $C / N$ analysis was carried out on 28 samples from the core, selected according to their organic matter content: a minimum of $5 \%$ by weight of organic matter was required to continue. The method by Stax and Stein (1993) was used as a basis for the preparation of the samples. Results were obtained using an elementary analyser (Vario Microcube, Elementar) coupled to a mass spectrometer (Isoprime 1000) (Fig. 4).

The bulk mineralogy was measured on 28 samples in the upper

Table 1

AMS Radiocarbon ages obtained from the materials of Crovani core. The calibrated ages are based on IntCal20 dataset (Reimer et al., 2020).

\begin{tabular}{|c|c|c|c|c|c|}
\hline LablID & Material & Depth $(\mathrm{cm})$ & ${ }^{14} \mathrm{C}$ Age \pm error BP & Cal. yr BP $(2 \sigma)$ & Cal. yr AD/BC $(2 \sigma)$ \\
\hline GdA-5806 & Organic sediment & 49 & $1585 \pm 25$ & $1527-1404$ & $423-546 \mathrm{AD}$ \\
\hline Poz-115,796 & Organic sediment & 50 & $3090 \pm 40$ & $3389-3179$ & $1440-1230 \mathrm{BC}$ \\
\hline GdA-5807 & Organic sediment & 77 & $2215 \pm 30$ & $2330-2146$ & $381-197$ BC \\
\hline GdA-5808 & Organic sediment & 93 & $2280 \pm 25$ & $2349-2177$ & 400-209 BC \\
\hline Poz-110,261 & Charcoal & 125 & $3260 \pm 90$ & $3699-3252$ & $1750-1301 \mathrm{BC}$ \\
\hline GdA-5809 & Organic sediment & 138 & $3090 \pm 35$ & $3382-3210$ & $1433-1261$ BC \\
\hline GdA-5810 & Organic sediment & 154 & $3215 \pm 30$ & $3480-3373$ & $1531-1424$ BC \\
\hline Poz-110,260 & Plant + Peat & 185 & $3420 \pm 35$ & $3823-3569$ & $1874-1620$ ВС \\
\hline GdA-5811 & Organic sediment & 229 & $4170 \pm 40$ & $4834-4577$ & $2885-2628$ BC \\
\hline Poz-110,258 & Peat & 270 & $4175 \pm 35$ & $4835-4580$ & 2886-2631 BC \\
\hline Poz-109794 & Charcoal & 340 & $4470 \pm 40$ & $5297-4967$ & $3348-3018$ BC \\
\hline Poz-110,198 & Peat & 397 & $4530 \pm 30$ & $5312-5051$ & $3363-3102$ BC \\
\hline Poz-109887 & Charcoal & 450 & $4730 \pm 40$ & $5581-5325$ & $3632-3376$ BC \\
\hline Poz-105992 & Bulk Sediment & 487 & $5080 \pm 40$ & $5917-5730$ & $3968-3781$ BC \\
\hline
\end{tabular}




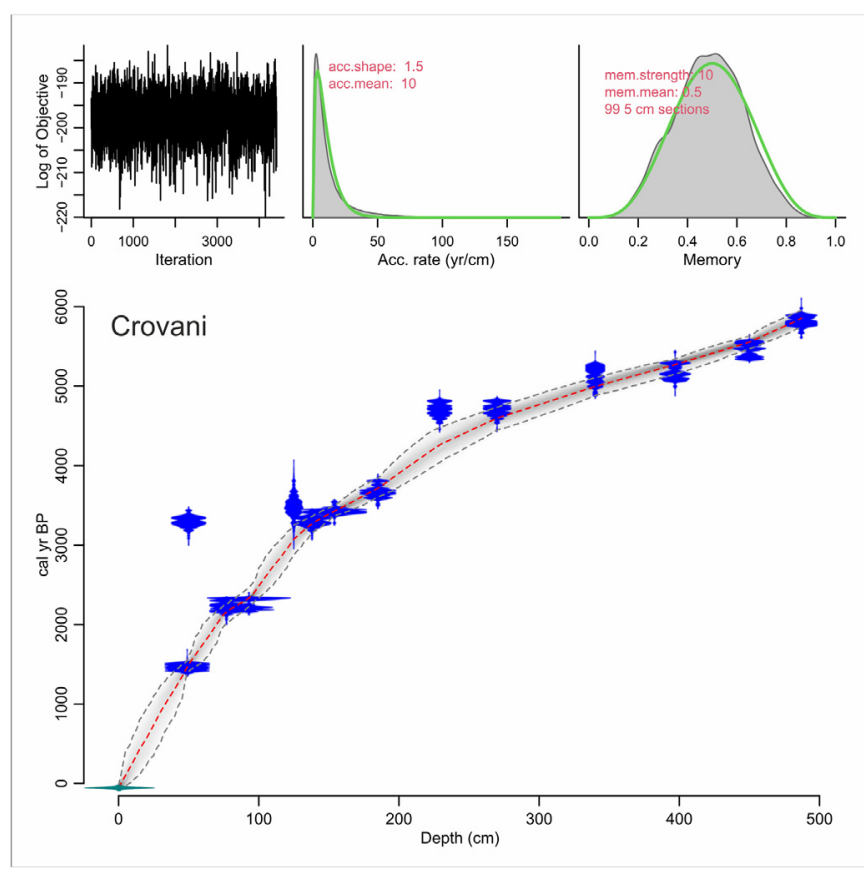

Fig. 3. Age-Depth Model of the Crovani sequence, calculated through a Bayesian method using the computer program Bacon 2.5.5 (Blaauw and Christen, 2011). The Model is based on 14 AMS dates calibrated using the IntCal20 curve (Reimer et al., 2020).

$261 \mathrm{~cm}$ of the core. Most of the samples were retrieved from clayey sediments between 116 and $261 \mathrm{~cm}$ (20 samples), with a sampling resolution of $4 \mathrm{~cm}$. In addition, 8 samples were retrieved between 11 and $106 \mathrm{~cm}$. About $1 \mathrm{~g}$ of dried bulk sediment sample was hand ground for mineralogical analyses. X ray diffraction (XRD) patterns of non-oriented powders (Moore and Reynolds, 1997) were acquired between 2 and $30^{\circ} 2 \theta$ angle by using a Bruker D8-Advance Eco $1 \mathrm{Kw}$ diffractometer equipped with a ceramic copper (Ka radiance with $\lambda=1.5418 \AA$ ). The XRD data measured under a current intensity of $25 \mathrm{~mA}$ and a voltage of $40 \mathrm{KV}$ were recorded with a Lynxeye Xe energy dispersive detector in the laboratory AGEs at the University of Liège. The minerals were identified by their peak positions and their abundance was calculated from the intensity of selected diffraction peaks (Cook et al., 1975).

The bulk samples for $\mathrm{Pb}$ isotopes analyses were digested using a tri-acid attack of $\mathrm{HF} / \mathrm{HNO}_{3} / \mathrm{HCl}$ in a laminar flow hood. The $\mathrm{Pb}$ purification was made according to the procedures published in Weis et al. (2006). The Pb isotopes were measured by static multicollection in dry mode on a Nu Plasma I MC-ICP-MS instrument at the University of Brussels. The values were normalized using the recommended NBS981 values $\left({ }^{208} \mathrm{~Pb} /{ }^{204} \mathrm{~Pb} \quad 36.7219 \pm 61\right.$, $\left.{ }^{207} \mathrm{~Pb} /{ }^{204} \mathrm{~Pb} 15.4963 \pm 17,{ }^{206} \mathrm{~Pb} /{ }^{204} \mathrm{~Pb} 16.9405 \pm 24\right)$ from Galer and Abouchami (1998). The $\mathrm{Pb}$ isotopes ratios were measured on 24 clayey samples retrieved in unit VI and VIII with a $\sim 5 \mathrm{~cm}$ sampling resolution between 11 and $260 \mathrm{~cm}$ (Table S1).

In addition, some Pb-bearing minerals were collected in different Corsican ores or mineralized veins on the Paleozoic granites from west Corsica (Fig. 5). We have sampled the main $\mathrm{Pb}$ mineral galena $(\mathrm{PbS})$ and also some $\mathrm{Pb}$-bearing minerals like arsenopyrite (FeAsS). Galena was sampled in the mine of Argentella, $2.5 \mathrm{~km}$ from the Crovani pond, but also in the mine of Lozari (along the northwestern coast, east of Île Rousse) and in a mineralized vein in Prunelli (south of Porto - see locations in Fig. 1). In addition, an arsenopyrite mineral sample was collected in the Finosa $\mathrm{Pb}-\mathrm{Zn}-\mathrm{Ag}$ ore close to Ghisoni (Fig. 1).
Pollen analysis was carried out on 62 samples. Pollen extraction followed the standard procedures summarized by Magri and Di Rita (2015). Pollen grains and NPPs were identified by light microscope at 400 and 640 magnifications, with the help of both pollen morphology atlases (e.g., Reille, 1992b; Beug, 2004) and NPPs reference articles (e.g., van Geel, 2001; Cugny et al., 2010; Gelorini et al., 2011).

Microcharcoal analysis was carried out to reconstruct fire history, following the procedures described by Clark (1982). A series of 150 microscope fields were checked for each sample. Microcharcoals smaller than $5 \mu \mathrm{m}$ were excluded from the sum. The computer program Psimpoll 4.27 (Bennett, 2009) was used to plot the percentage and concentration diagrams, as well as to subdivide the pollen record into 8 local assemblage zones, numbered from the base upwards and prefixed by the site abbreviation CRO, by means of the CONISS method (Grimm, 1987).

A REDFIT spectral analysis (Schulz and Mudelsee, 2002) using the PAST 3.2 software (Hammer et al., 2001) was applied to the unevenly spaced time series represented by the total Arboreal Pollen (AP) percentages to detect the possible occurrence of a fundamental tempo in the forest cover changes.

\section{Results}

\subsection{Chronostratigraphy}

Based on the laser grain size determination and on the organic matter/carbonate contents, eight stratigraphic units were defined from the bottom to the top (Fig. 4).

Unit I is found between 6.25 and $5.95 \mathrm{~m}$ depth. It consists of a mixture of well-rounded pebbles cemented within a sandy matrix and grey clays containing from 2 to $5 \%$ of organic matter. Due to the paucity of organic material, radiocarbon dating of this sedimentary unit was impossible.

Unit II is found between 5.95 and $5.45 \mathrm{~m}$ depth. It comprises medium to coarse grey sands with local intercalations of angular gravels (centimetric in size). Organic matter and carbonate content are very low $(1-2 \%)$, hindering any radiocarbon dating of Unit II. No biomarkers were identified.

Unit III is encountered between 5.45 and $3.73 \mathrm{~m}$ depth ( 63005170 cal. BP; 4350-3220 BC). It consists of homogeneous grey clays. The organic matter content ranges between 10 and $15 \%$ while carbonate content shows values comprised between 6 and $9 \%$.

Unit IV occurs from 3.73 to $2.95 \mathrm{~m}$ depth (5170-4760 cal. BP; 3220-2810 BC). It shows features similar to Unit II. It consists of coarse sands with intercalated layers of gravels with sharp edges, witnessing variations in the energy of deposition, in particular at the point of changeover with Unit III. In the lowermost part of Unit IV, a layer of $15 \mathrm{~cm}$ consists of angular gravels without sedimentary matrix. Organic matter and carbonate contents (both $<2 \%$ ) are low, like Unit II. Radiocarbon dating of this lowermost portion is consistent with a time interval encompassing the Late to Final Neolithic.

Unit V, between 2.95 and $2.72 \mathrm{~m}$ depth (4760-4630 cal. BP; 2810-2680 BC), consists of organic coarse sandy clays. Organic matter content increases upwards (1-7\%). The carbonates content is lower than $2 \%$.

Unit VI is found from 2.72 to $1.42 \mathrm{~m}$ depth (4630-3320 cal. BP; 2680-1370 BC) and exhibits sedimentological parameters similar to Unit V. It consists of organic clays with $10-20 \%$ of organic matter and $\leq 8 \%$ of carbonate. The XRD mineralogy (Fig. S1) reveals the dominance of detrital minerals ( $50 \%$ of quartz, K-feldspars and plagioclase with traces of amphibole and chlorite). They are associated to clayey minerals ( $30 \%$ of total undifferentiated clays), aragonite (3-8\%) from biogenic fragments and evaporites 


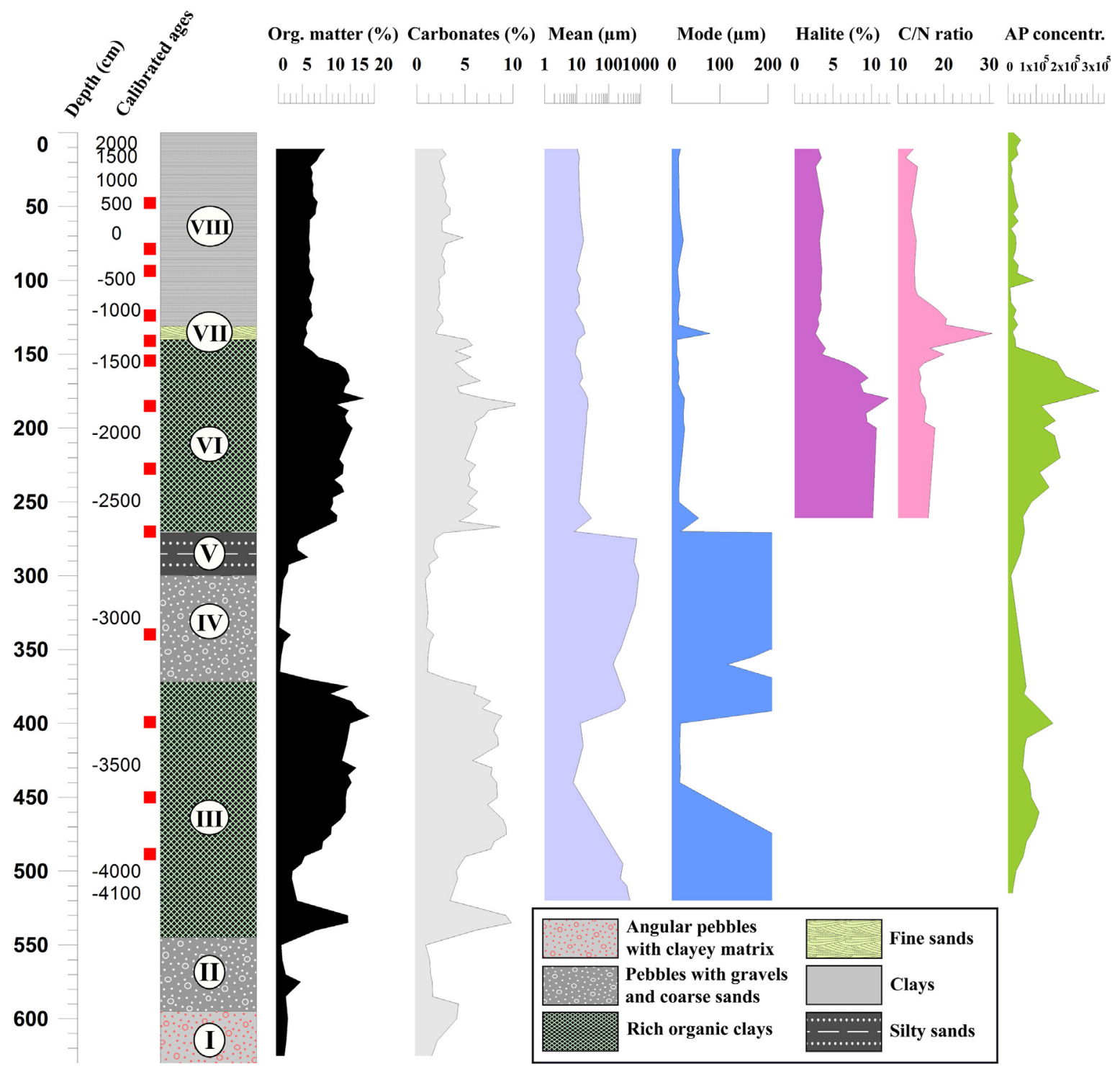

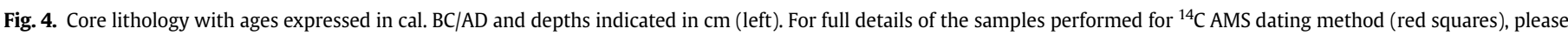

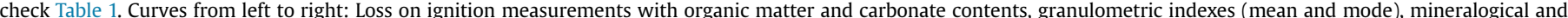

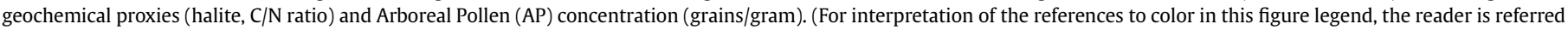
to the Web version of this article.)

( $8 \%<$ halite $<12 \%$ - Fig. 4). Radiocarbon dating of the unit is consistent with a time interval ranging from Final Neolithic to Middle Bronze Age.

Unit VII is encountered from 1.42 to $1.32 \mathrm{~m}$ deep (3320-3190 BP; $1370-1240 \mathrm{BC})$. It consists in a thin layer $(10 \mathrm{~cm})$ of homogeneous yellow fine sands showing a modal index of $90 \mu \mathrm{m}$ with a mean grain size of $20 \mu \mathrm{m}$ (fine silts). The granulometric analyses exhibit a multimodal distribution of the particles. Positive excursion in detrital minerals (cumulated abundance over 70\%). Is observed for Unit VII and corresponds to a significant increase in quartz (28\%) and plagioclase (25\%) and a relative drop in total clays minerals (13\%) (Fig. S1).

Sedimentary Unit VIII is identified in the uppermost $1.32 \mathrm{~m}$ depth (3190-0 cal. BP; 1240 BC-1950 AD). Homogeneous grey clays record numerous traces of oxidation corresponding to rootlets. The organic matter content is homogeneous $(6-8 \%)$, while carbonate content is low (2-3\%). The XRD mineral association remains similar to unit VI, except the abundance of evaporites. A drop of halite below 4\% occurs between 166 and $150 \mathrm{~cm}$, i.e. in the upper part of unit VII but close to the transition with unit VI (Fig. 4). The rate of sediment accumulation for Unit VIII is very low, with values of $\sim 4.3 \mathrm{~mm}$ per century.

\section{2. $C / N$ results}

The uppermost $2 \mathrm{~m}$ sediment, spanning the last four millennia, were investigated for $\mathrm{C} / \mathrm{N}$ ratio (Fig. 4). The averaged $\mathrm{C} / \mathrm{N}$ ratio is high ( $>10)$ and exceeds a value of 16 above $1.16 \mathrm{~m}$ suggesting a mainly terrestrial origin of the organic matter. The values range between 11 and 14 from 1.16 to $2 \mathrm{~m}$, indicating a mixture of organic matter from vascular plants and algae. The highest value $(\sim 30)$ measured at $1.36 \mathrm{~m}$ indicates an episode of high input of sediments of continental origin, with a mix of vascular plants and cellulosic plants, dated ca. 1430 to $1260 \mathrm{BC}$. 


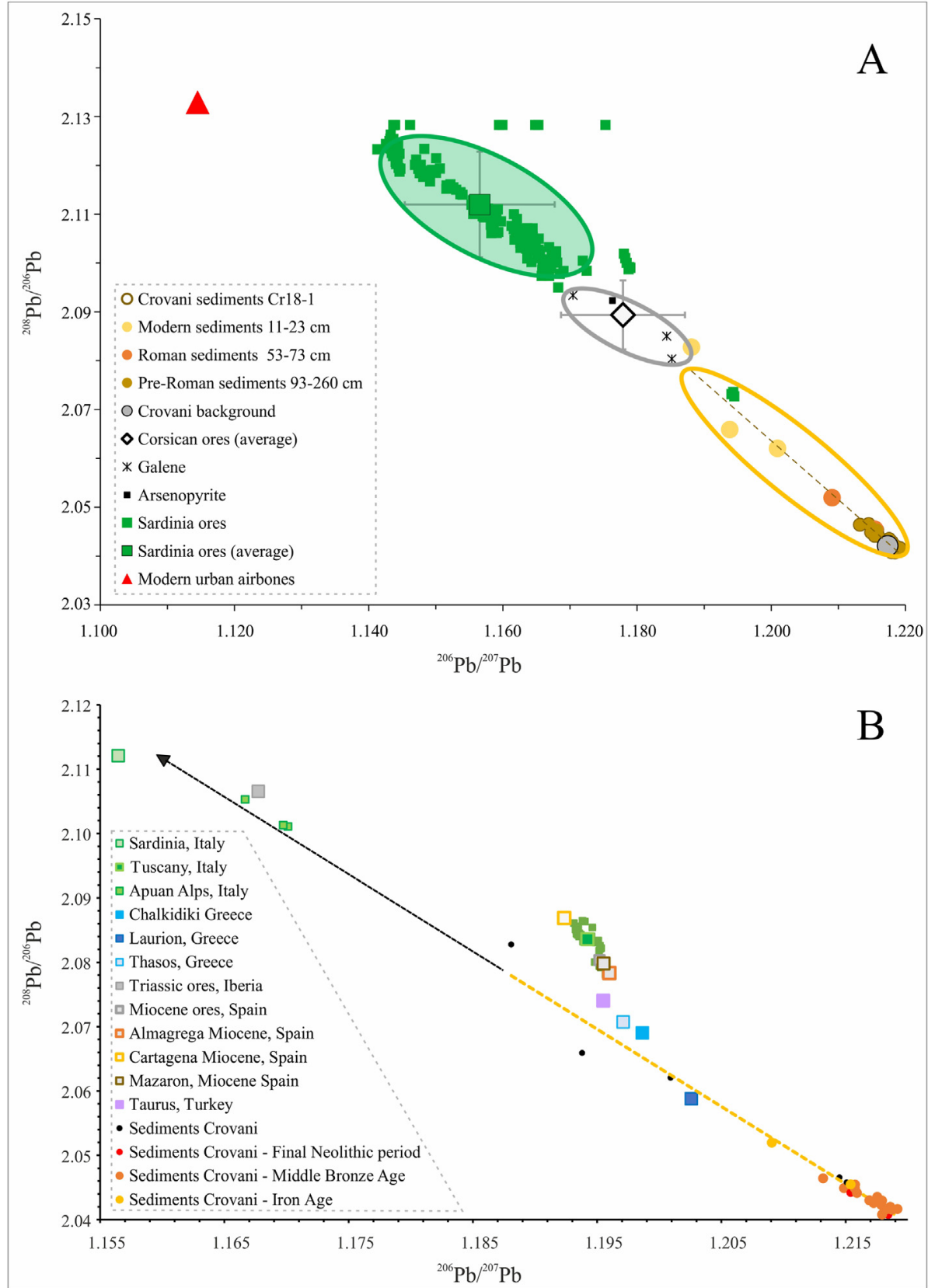

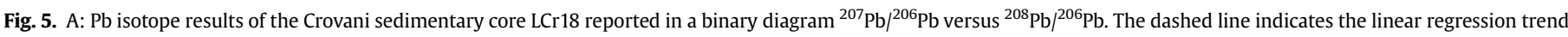

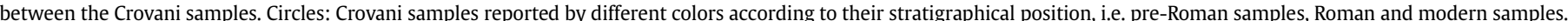

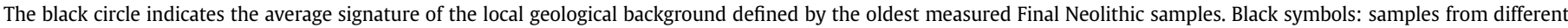

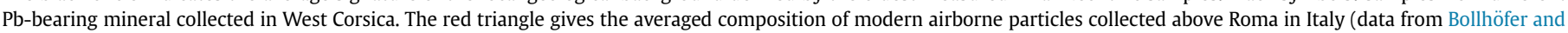

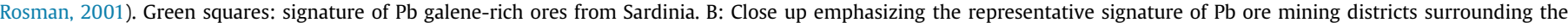

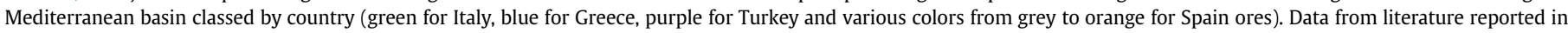

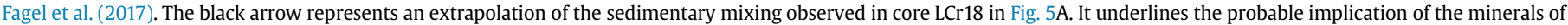

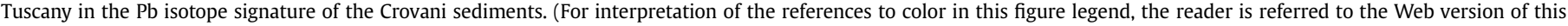
article.)

\subsection{Lead isotopes analyses}

The three $\mathrm{Pb}$ isotopic ratios evolve in parallel in the 260-upper $\mathrm{cm}$, from Final Neolithic to present (Fig. S2). The ${ }^{208} \mathrm{~Pb} /{ }^{204} \mathrm{~Pb}$ ranges between 38.60 and 39.01 (average $38.9353 \pm 0.0019$ ), the ${ }^{207} \mathrm{~Pb} /{ }^{204} \mathrm{~Pb}$ between 15.65 and 15.68 (average $15.6703 \pm 0.0007$ ), and the ${ }^{206} \mathrm{~Pb} /{ }^{204} \mathrm{~Pb}$ between 18.61 and 19.11 (average $19.02 \pm 0.0008$ ) (Table S1). Even if some scattering of the data is observed for the studied pre-Roman period (i.e., $260-93 \mathrm{~cm}$ ), the isotopic $\mathrm{Pb}$ ratios depict a marked decreasing trend upwards. This major change starts at $73 \mathrm{~cm}$ (Fig. S2) during the Roman period and continues over the modern period. The lowest isotopic ratios are measured in the shallowest samples at 11 and $17 \mathrm{~cm}$.

\subsection{Pollen analysis and statistical analysis on pollen time series}

The results of pollen analysis are presented as: 1) a detailed percentage diagram, including most of the pollen taxa and a 

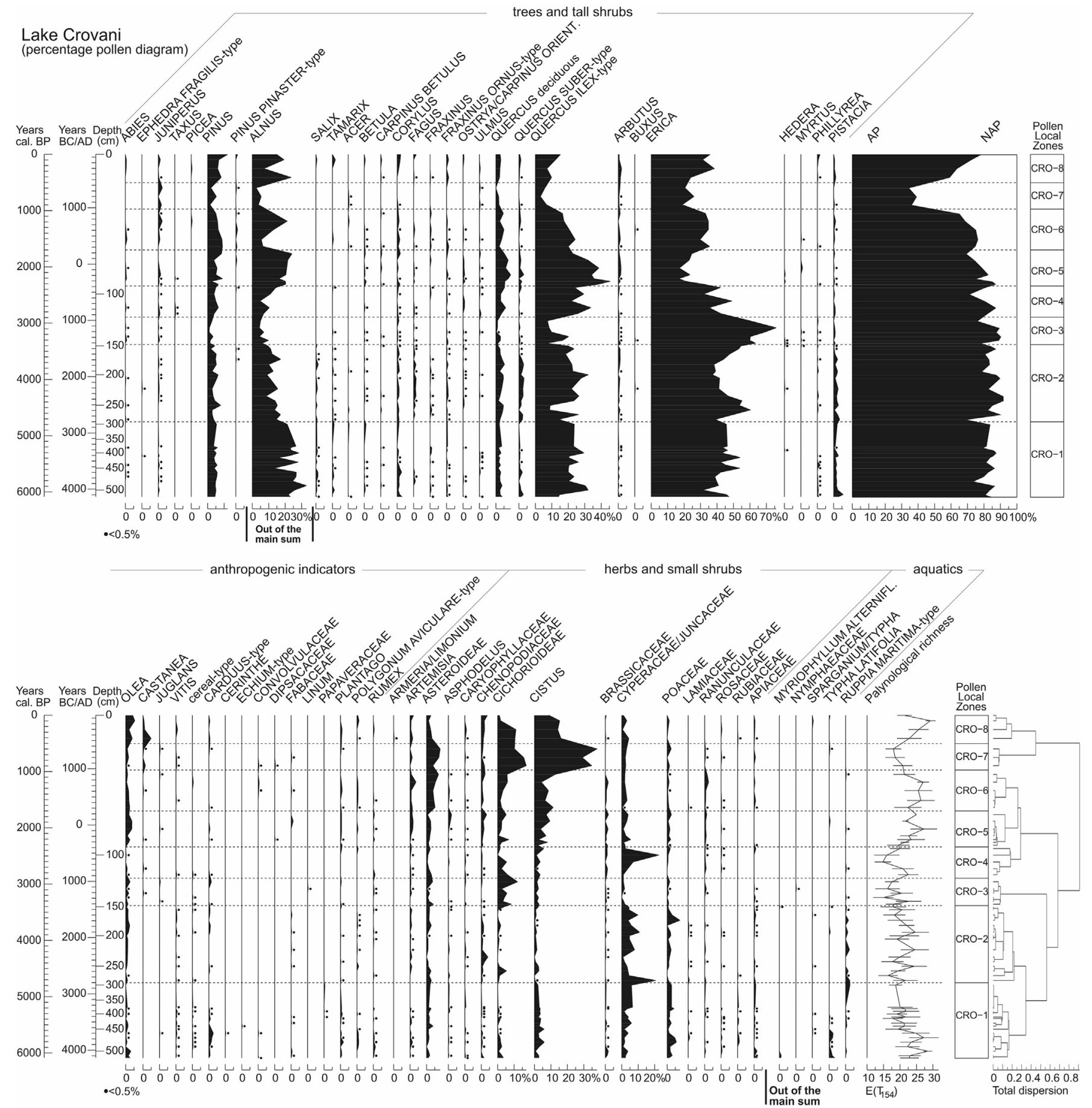

Fig. 6. Pollen percentage diagram of Crovani, including the pollen zonation calculated with the CONISS method (Grimm, 1987).

summary Arboreal Pollen (AP)/Non Arboreal Pollen (NAP) percentage diagram, plotted against age (Fig. 6); 2) a percentage diagram displaying the main NPPs (Fig. 7); 3) a synthetic diagram including cumulative pollen percentages of ecological groups (conifers, riparian trees, deciduous trees, evergreen trees and shrubs, OJCV (Olea + Juglans + Castanea + Vitis), anthropogenic herbs, other herbs, coprophilous fungi, and saproxylic and phytopathogenic fungi), AP percentage, the concentrations of AP and NAP, microcharcoals, and some climate proxies (Fig. 8).

The pollen preservation was good with percentages of undeterminable grains rarely higher than $4 \%$. On average, 310 pollen grains of terrestrial taxa were counted per sample. The biodiversity was represented by 92 different pollen taxa (terrestrial + aquatic plants) summed to 45 types of ferns, algae, fungi, and other NPPs. The palynological richness, estimated by rarefaction analysis (Birks and Line, 1992), is always over 15 terrestrial pollen types per sample. Total pollen concentrations vary from 7000 to 321,000 terrestrial pollen grains/g sediment. The features of the local pollen assemblage zones are summarized in the Supplementary Materials.

A REDFIT analysis was applied to the unevenly sampled time series represented by the total AP percentages, which show a clear fluctuating trend consistent with changes in forest cover rather 


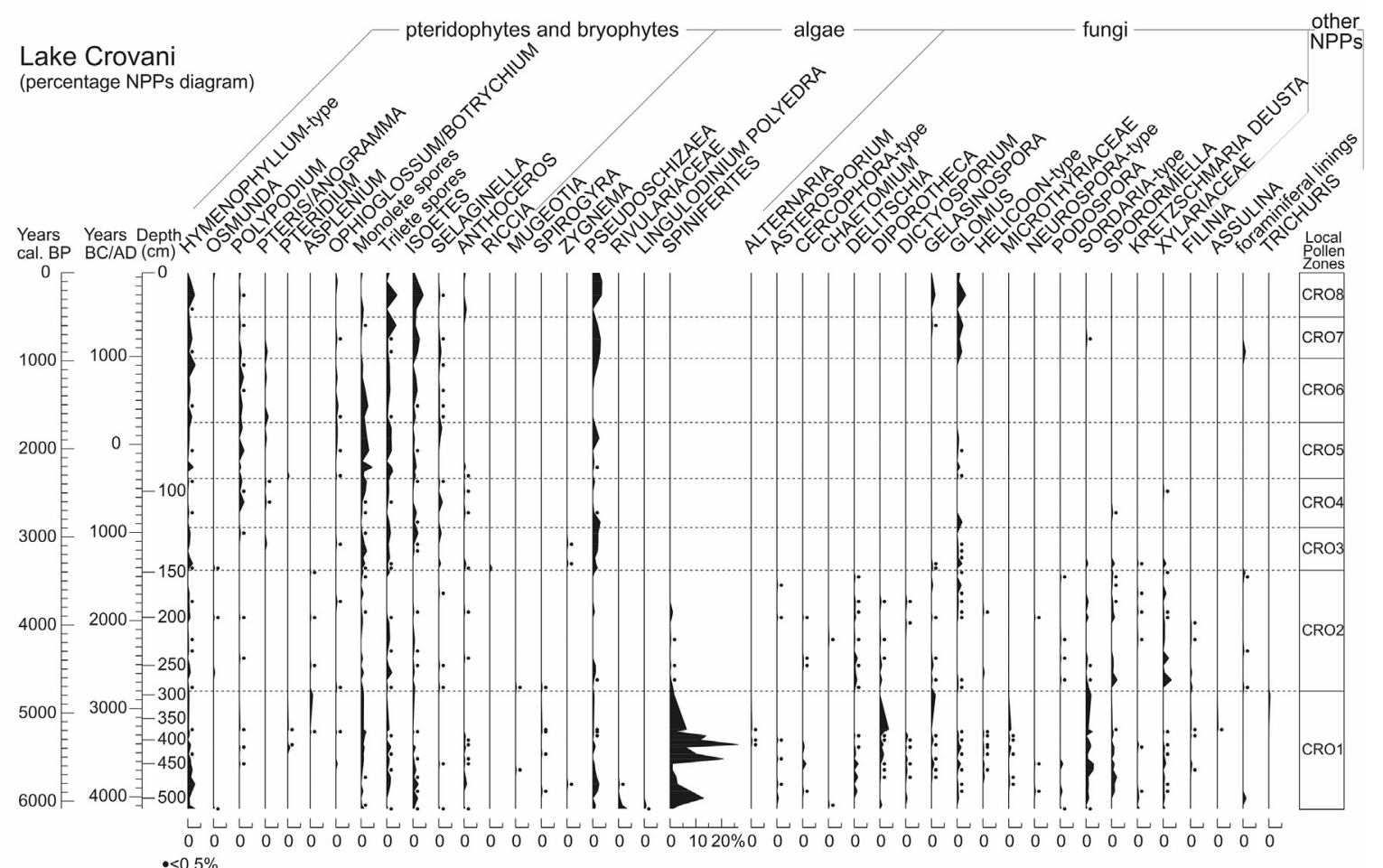

Fig. 7. Percentage diagram of Non-Pollen Palynomorphs from Crovani.

than random fluctuations due to pollen representation and preservation (Fig. 9).

The results of the REDFIT exhibit a peak in power spectrum exceeding $95 \%$ of the false-alarm levels of both $\chi^{2}$ and Monte Carlo tests, corresponding to a statistically significant periodicity of ca. 228 years (time $=1$ /frequency), and less significant frequencies centred at 996 and 430 years, which however exceed $90 \%$ of the false-alarm levels of both $\chi^{2}$ and Monte Carlo tests (Fig. 9).

\section{Discussion}

\subsection{Evolution of the vegetational landscape}

During the Middle and Late Holocene, from ca. 6100 to 1000 cal. BP (4150 BC-950 AD), the Crovani pond was surrounded by a dense Erica-dominated tall maquis, accompanied by several evergreen elements, such as Q. ilex, Phillyrea, Pistacia, and Olea (Figs. 6, 8 and

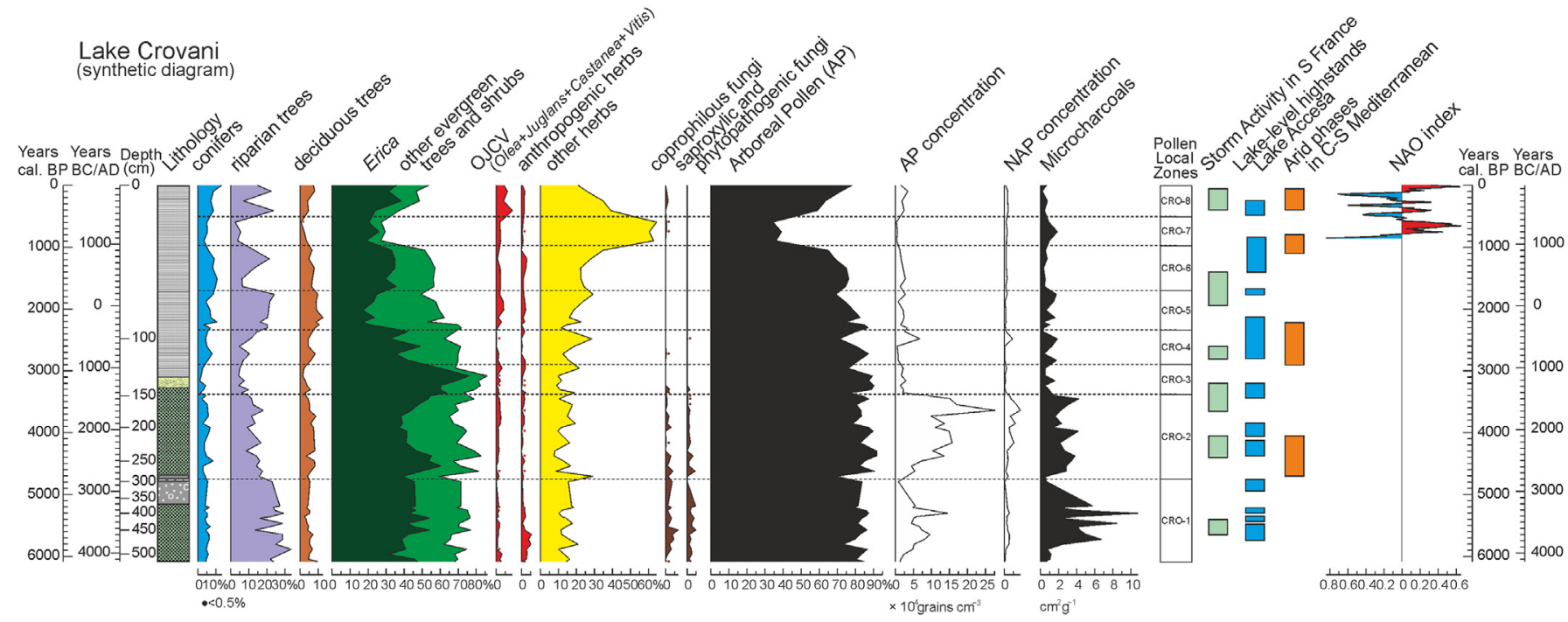

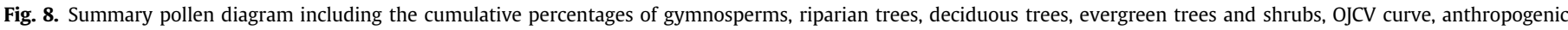

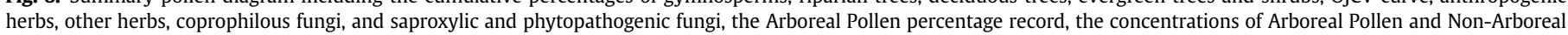

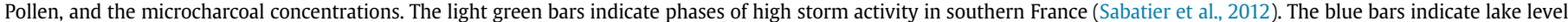

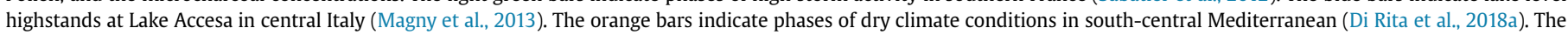
NAO index is based on Franke et al. (2017). (For interpretation of the references to color in this figure legend, the reader is referred to the Web version of this article.) 


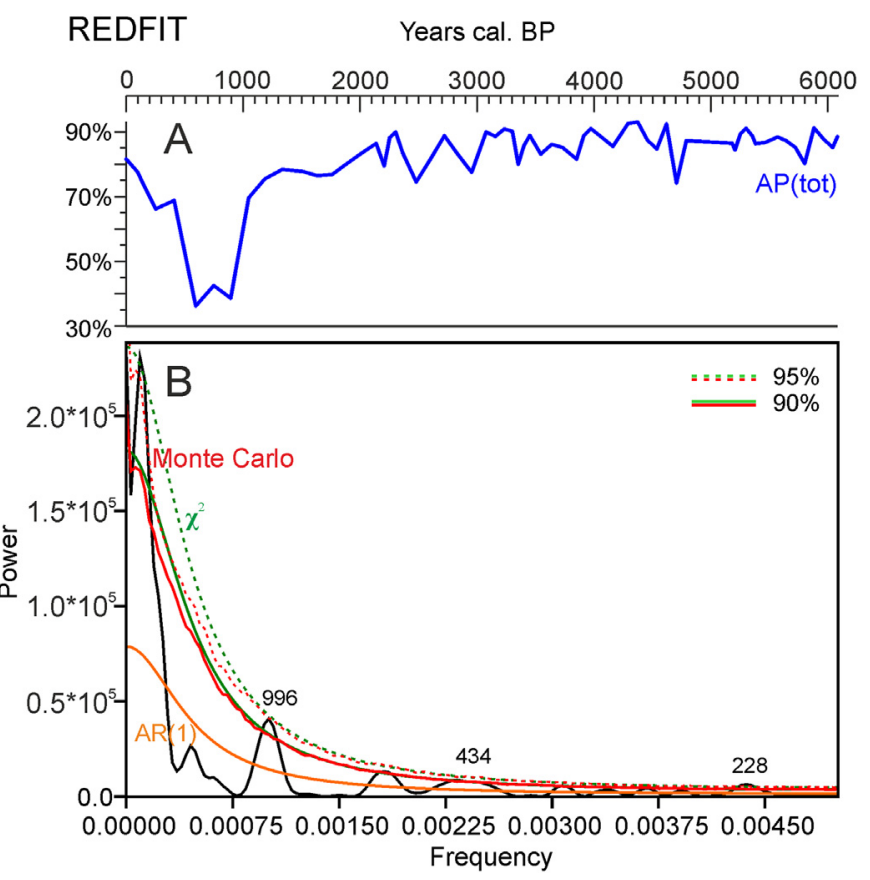

Fig. 9. REDFIT (A) analysis of the total Arboreal Pollen percentages (B) using the PAST 3.2 software program (Hammer et al., 2001). In the REDFIT spectral analysis the time series is fitted to an AR1 red noise model (orange line). The 95\% confidence levels of the $\chi^{2}$ and Monte Carlo tests are reported on the graph with a green dashed line and a red dashed line, respectively. (For interpretation of the references to color in this figure legend, the reader is referred to the Web version of this article.)

10). This observation is consistent with other palynological studies from southern Corsica (Reille, 1975, 1984; Revelles et al., 2019; Vella et al., 2019) and on the Cavallo island, situated in the strait of Bonifacio (Poher et al., 2017). An almost continuous record of Arbutus indicates that strawberry trees was a common presence in the Erica arborea formations, as its pollen tetrads are poorly dispersed. The most degraded sectors of this maquis vegetation were probably occupied by law shrublands of Cistus, which played a prominent role in the dune and sandy soil vegetation together with Olea, Pistacia and other thermophilous shrubs, as also reported from other coastal sites of western Corsica (Reille, 1992a).

The pollen record from Crovani provides new data to investigate the complex interplay between Erica-dominated and $Q$. ilexdominated vegetation and their turnover in Corsica. According to Reille (1992a), Erica woodlands, representing the climax vegetation in lowland areas of western Corsica, underwent a major degradation process since the neolithization of the island, as a result of increasing human impact. It was largely replaced by Quercus ilex during the Mid-to Late Holocene (Reille, 1992a; Carcaillet et al., 1997). Recent palynological studies (Revelles et al., 2019) confirmed the anthropic causation of this vegetation turnover and suggested that it started with the development of agropastoral practices during the Early Neolithic, hence significantly earlier than the period previously identified by Reille (1992a). Similar vegetation dynamics were reported also in Sardinia, where a clear development of Quercus ilex, leading to a partial or complete replacement of the late successional Erica shrublands, is recorded since the $6^{\text {th }}$ millennium BP (Di Rita and Melis, 2013; Beffa et al., 2016; Melis et al., 2017, 2018; Pedrotta et al., 2021). In contrast, the pollen record from Crovani (Fig. 6) indicates that the frequencies of Erica were continuously high until $2900 \mathrm{BP}$ and were not replaced by $Q$. ilex. Our pollen record even shows two temporary major increases in Erica at the expense of holm oaks in the time-intervals $4700-4300$ and 3350-2900 cal. BP. High frequencies and concentrations of Erica and Q. ilex concur in depicting a maquis characterized by high biomass and decomposed organic matter, as suggested by generally high values in the loss of ignition and a significant presence of saproxylic and phytopathogenic fungi, such as Kretzschmaria deusta, Asterosporium and Xylariaceae (Fig. 7).

In Sardinia, Beffa et al. (2016) hypothesize that a protracted dominance of Erica and the absence of evergreen oak forests in the first part of the Middle Holocene (until ca. 5300 cal. BP) were related to warmer/drier summers and cooler/moister winters than today. They suggest that also in Corsica such a climate regime,

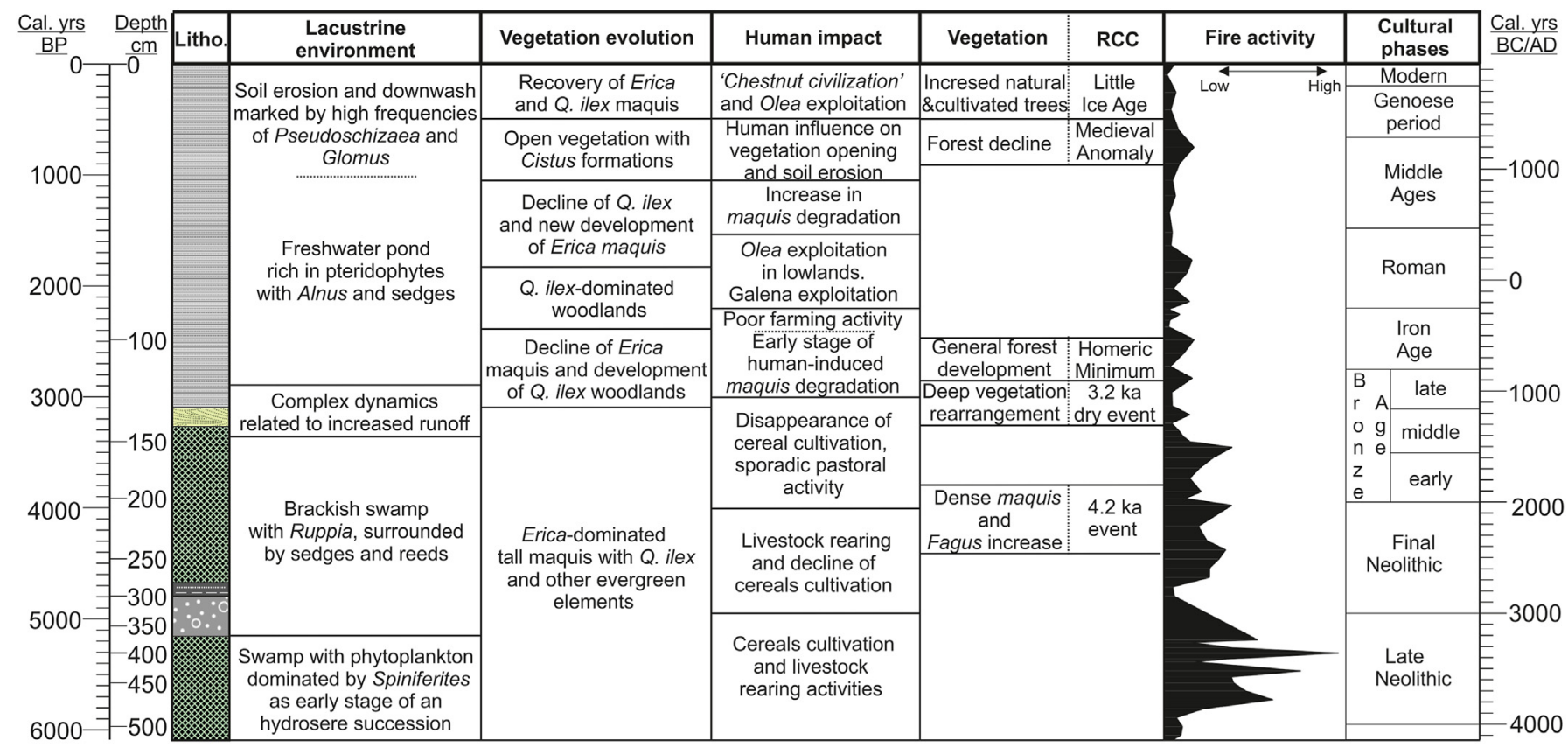

Fig. 10. Synoptic table with timing and nature of key environmental changes reconstructed from the Crovani record. 
characterized by frequent and prolonged droughts during the spring and summer, may have led to frequent seasonal wildfires advantaging communities dominated by Erica scoparia and Erica arborea, which are two fire-adapted species able to quickly resprout and generate new aboveground biomass after frequent and intense fires. In contrast, Quercus ilex is considered to have been severely affected by natural and anthropogenic fires and favoured by a climate change leading to increased summer rainfall and decreased fire occurred at the end of the Middle Holocene (Colombaroli et al., 2009; Beffa et al., 2016; Pedrotta et al., 2021).

In contrast to this view, at Crovani, high concentrations of microcharcoal, reflecting fires, are recorded in correspondence of high values of both Erica and Q. ilex. Contemporary high values of Q. ilex and microcharcoal support the interpretation of Reille (1992a) and Carcaillet et al. (1997), which suggest that the development of holm oak in Corsica was triggered by anthropogenic fires. At Crovani, a substantial portion of the Mid-Holocene fires may be related to human activity, which is witnessed by a significant presence of anthropogenic indicators (Figs. 6-8). High frequencies of microcharcoal in zones CRO- 1 and CRO-2 are consistent with the coeval high incidence of fires recorded in the region (Leys et al., 2014; Lestienne et al., 2020a, b), most of which are attributed to human activity. According to Lestienne et al. (2020b), since 5000 cal. BP humans have taken control of the fire regime through agro-pastoralism, favouring large and/or frequent fire events. For the same reason, the marked decrease in microcharcoal recorded at Crovani during the Late Holocene after 3350 cal. BP, which matches a decrease in anthropogenic pollen indicators, may reflect decreased human activity, at a time of an unsuitable climate for fires.

Starting from $\sim 2900$ cal. BP, there was a general decline in Erica, opposed to an increase in holm oaks, which led to a turnover of the two woody taxa between 2300 and 1900 cal. BP. At this timeinterval, an increase in oaks may have been influenced by the forestry practices of Roman times. All the same, in the last 2500 years, a clear development of cork oak in Corsica (Reille, 1984, 1992a), Sardinia (Di Rita and Melis, 2013), and the western Iberian Peninsula (Carrión et al., 2000) may be related to silvicultural practices.

Between 1900 and 1000 cal. BP (pollen zone CRO-6), a new moderate increase in Erica at the expense of $Q$. ilex suggests a new expansion of the native Erica-dominated shrublands.

Between 1000 and 500 cal. BP (pollen zone CRO-7), a major degradation of the forest cover is recorded, with a massive decline of the tall maquis that was replaced by Cistus-dominated low shrubland. After $\sim 500 \mathrm{BP}$, Erica and Q. ilex recovered, as recorded also in other sites of Corsica (e.g. Vella et al., 2019).

Modest oscillations of deciduous trees throughout the record (Figs. 6 and 8) suggest that they were scarcely involved in the environmental processes influencing the evergreen vegetation, probably because they were located at higher elevations in the island. Frequent finds of mesophilous trees such as Fagus and Betula, which require temperate and humid conditions, confirm that part of the pollen rain originated from the montane vegetation belt. The fingerprint of deciduous trees in the pollen record of Crovani, as in other coastal pollen records of Corsica (Reille, 1992a; Currás et al., 2017; Revelles et al., 2019), is clearly due the steep topography of the island, which determined a relatively low distance of montane and sub-montane vegetation belts from the coast. However, it cannot be excluded that sparse stands of mixed oak communities could also be preserved in humid areas at low elevations, especially inside floodplain and riparian woodlands, dominated by Alnus, accompanied by Salix, Tamarix, and possible wild Vitis, which are still documented in the area (Reille, 1992a).
Conifers are mostly represented by Pinus, substantially reflecting the persistence of Pinus nigra subsp. laricio at montane and submontane elevations since the late glacial period (Leys et al., 2014). The occurrence of Pinus pinaster since the Bronze Age is probably related to human activity (Reille, 1992a). In addition to pine, conifers include taxa distributed in both lowland/coastal areas, such as Juniperus, and in montane sectors, such as Abies and Taxus (Fig. 7). Rare occurrences of Picea, whose current natural range does not include Corsica (Caudullo et al., 2016), are of distant origin.

\subsection{Environmental responses to hydrological and morphosedimentary processes}

The local aquatic environment outlined by the pollen record ranged from brackish (6100-3400 cal. BP) to freshwater conditions ( 3400 cal. BP-present day) (Fig. 10). This range is documented by the presence of freshwater taxa, such as Spirogyra, Zygnema and Myriophyllum, salt-tolerant species, such as Ruppia maritima, and marine organisms, represented by foraminiferal linings, pointing to inputs of salt-water into the pond (Bellotti et al., 2016). This was likely related to the morphological response of the pond to the Mediterranean sea-level rise whose average rates decreased from $\sim 2 \mathrm{~mm} \mathrm{a}^{-1}$ at $\sim 6100$ BP to less than $\sim 0.5 \mathrm{~mm} \mathrm{a}^{-1}$ in the last 3500 years (Vacchi et al., 2021). These major changes in the rising rates probably have an influence on the connection of the pond with the open sea as already observed in lagoonal setting both in Corsica (e.g. Vacchi et al., 2017; Revelles et al., 2019) and in Sardinia (Melis et al., 2017, 2018). However, the absence of fossil faunal associations hampered a detailed reconstruction of the nature of this backshore environment and its millennial evolution.

The lower part of the record ( 6100- 4800 cal. BP) is characterized by high frequencies of Spiniferites sp. (Fig. 7), dinoflagellate cysts often difficult to identify at the species level by routine observation in light microscopy (de Vernal et al., 2018). The genus Spiniferites is characterized by marine species, but it cannot be excluded that some Mediterranean species live in freshwater environments (Kouli et al., 2001; Zonneveld et al., 2013). Based on pollen records obtained from central Mediterranean regions, the presence of Spiniferites is often associated to brackish water (Di Rita et al., 2018b). Irrespective of water salinity, high frequencies of Spiniferites in the lower part of the Crovani sequence may reflect the pioneer stages of a hydrosere succession connected to the early phases of development of the coastal pond.

From $\sim 4800$ to $\sim 3350$ cal. BP (zone CRO-2), a significant increase in Ruppia maritima, a submerged angiosperm with large salinity tolerance (Kantrud, 1991), coupled with occurrences of foraminiferal linings, highlights a brackish environment. It is consistent with the observed presence of halite in unit VI (Fig. 4). Beds of submerged widgeongrass plants usually occur on muddy sand and mud in brackish pools. They accumulate sediment and may be associated with terrestrial saltmarsh plants, forming a hydrosere succession in coastal wetlands (Rodwell, 2000).

Starting from 3350 cal. BP, the abrupt decrease in Ruppia and the disappearance of most spores of fungi, coupled with a major increase in Pseudoschizaea (2\%) and fern spores, are the results of complex sedimentological and ecological changes leading to a lowering of the water level and to the establishment of the presentday marshy environments. Pseudoschizaea suggests both desiccation (Scott, 1992) and freshwater flows accompanied by erosive processes, sometimes associated with runoff events (PantaléonCano et al., 2003), while the disappearance of most fungal spores, the decrease in pollen concentrations, and the high percentages of Cichorioideae (Figs. 6-8) can be interpreted as selective preservation of palynomorphs (Bottema, 1975; Havinga, 1984). 
It is noteworthy that Reille (1992a) recorded a sharp drop in Ruppia at $150 \mathrm{~cm}$ depth and correlated it with a local change in sediment accumulation. This was caused by an event of forest clearance, followed by an increase in runoff, leading to the accumulation of a sandy layer and a significant development of ferns. In our record, a phase of increased terrestrial runoff is revealed by an input of organic matter of continental origin recorded by a positive excursion of $\mathrm{C} / \mathrm{N}$ ratio at $1.36 \mathrm{~m}$ (ca. 3250 cal. BP - Fig. 4) and by a significant increase in detrital minerals (Fig. S1), but is not preceded by clear changes in AP percentages that may testify to a deforestation process, although there is a drop in AP concentrations around 3350 cal. BP. A clearance of local shrubs, represented by a sharp decline in Erica frequencies, was recorded only after $~ 3100$ cal. BP (Figs. 6 and 8).

Summarizing, initially the opening of the vegetation did not change the composition of the shrubland, which was later affected by the drop of Erica. Sedimentological analyses indicate an increase of the granulometry within a broader context of swamp environment of deposition characterized by homogeneous clays. At $\sim 136 \mathrm{~cm}$ depth (ca. $3250 \mathrm{cal}$. BP), there is an event of higher energy of deposition characterized by the punctual presence of coarse silts to fine sands. In the Canniccia pond, located in SW Corsica, Ghilardi et al. (2017b) and Vella et al. (2019) identified a high detrital input dated ca. 3350 cal. BP. At a regional scale, the southern France recorded an intense phase of alluviation within the Rhone drainage basin (Berger et al., 2007) and the Pyrenean mountains (Galop et al., 2007). This is possibly explained by the occurrence of a cooler and more arid period that resulted in deforestation on a regional scale (Ghilardi et al., 2017a), recognized in western Mediterranean pollen records (Carrión, 2002; Fletcher et al., 2013) and in speleothems from Tuscany located only ca. $200 \mathrm{~km}$ from Crovani (Regattieri et al., 2014). However, the eastern coast of Corsica did not record such event (Currás et al., 2017), which seems to have especially affected western Corsica.

Since 2900 cal. BP, an expansion of ferns and other hydrophytes (Fig. 7) suggests stagnant water, which may have been produced by a lowering of the lake enhanced by runoff, sediment infilling, and a salinity change towards more freshwater conditions. This change is confirmed by the observed decrease in the halite since the final part of units VI (Fig. 4). Such pattern is consistent with a substantial sealevel stability, which occurred in the NW Mediterranean Sea in the last 2000 years (Vacchi et al., 2021). This stabilization process significantly decreased the salinity input within the pond triggering the progressive transition in pure freshwater environment.

Overall, the sequence dinoflagellates (Spiniferites) $\rightarrow$ acquatic plants (Ruppia maritima) $\rightarrow$ ferns profiled throughout the pollen record corresponds to a hydrosere succession, whose evolution is strictly related to the sediment infilling of lakes (Fig. 6). This ecological succession typically involves reed swamp vegetation at an intermediate stage, here represented by pollen of Cyperaceae and partly of Poaceae, and Alnus at a mature stage. In several coastal sedimentary archives of the central Mediterranean, temporary expansions of Cyperaceae and Poaceae are followed by an increase in Alnus (Magri et al., 2019 and references therein). At Crovani this pattern is especially clear in the interval between $\sim 2600$ and $\sim 1700$ cal. BP, when complete hydrosere succession with a climax woodland stage occurred in marginal sectors of the basin, in relation to a lagoon reduction (Fig. 6).

\subsection{Human impact on the landscape}

Human activity is evident throughout the pollen record with different intensity and type of land use (Fig. 10). During the Late Neolithic, from $\sim 3900$ to $\sim 3250$ BC, the continuous curve of cerealtype pollen testifies to early cultivations (Fig. 6). Evidence for agriculture is also observed at the Saint Florent site starting from $\sim 4000$ cal. BC (Revelles et al., 2019), but only the extreme south of the island (Bonifacio-Piantarella area) exhibits continuous agricultural practices all along the Neolithic period. At Crovani, the pollen record reveals human activity older than the archaeological finds, indicating that farming was practiced $\sim 1000$ years before the earliest trace of human occupation at the Teghja di Linu site (Sicurani and Martinet, 2019).

Cereal cultivation appears associated to livestock rearing activities, which contributed to the development of disturbed meadows, as highlighted by a significant record of Sporormiella, Sordaria, and Podospora, and by pollen indicators for Mediterranean pasturelands, such as Carduus-type, Plantago, Polygonum aviculare-type, as well as some species of the subfamilies Asteroideae and Cichorioideae (Desprat et al., 2013; Florenzano et al., 2015) (Figs. 6 and 8). The high values of microcharcoal may partly reflect the use of fire for farming purposes, such as slash-and-burn practices, which however did not affect the fire-adapted local shrubland. In general, human activity during the Late Neolithic certainly influenced the vegetation evolution of the area, but its impact did not induce a marked local deforestation. While we cannot advance any precise explanation for this pattern, we can speculate that local settlements were not populated enough to induce forest declines detectable in the pollen diagram.

During the Final Neolithic and Bronze Age (from 3000 to 800 $\mathrm{BC})$, both cereal cultivation and livestock rearing appear less intense and discontinuous. The archaeological history of Corsica indicates that Early to Middle Bronze Age are periods of human implantation in the upper part of the hills (Casteddi) when lowlands and coastal areas were less occupied (Cesari and Pêche Quilichini, 2015). The pollen record from Crovani confirms this pattern, even if in some coastal areas the Mid-to Late Bronze Age corresponds to a phase of renewed agriculture (Ghilardi et al., 2017a).

In the Iron Age, cereals disappeared and scattered occurrences of pasture weeds (e.g., Carduus, Plantago, and Rumex) testify to poor farming practices addressed to livestock rearing, suggesting a scarce human frequentation in the area (Fig. 6).

Human activity at Crovani is also revealed by the record of cultivated trees (OJCV curve, Fig. 8), which also include pollen of wild individuals of Olea and Vitis that is difficult to differentiate from pollen of cultivated plants (Reille, 1992a).

In the period encompassing the Neolithic to the Bronze Age, the pollen record of Crovani shows some early occurrences of Juglans (ca. 3700 BC) and Castanea (ca. 1200 BC) (Fig. 6). Similar early finds are also recorded in pollen diagrams from recently published coastal sites (Poher et al., 2017; Currás et al., 2017; Revelles et al., 2019). Although these occurrences are generally found during phases of intense human activity, as confirmed by the presence of other anthropogenic pollen indicators, it is difficult to hypothesize that cultivation of these trees was so early, without a clear archaeobotanical evidence. Unfortunately, the palynological studies of Reille (1992a, 1999) and Lestienne (2020a) do not contribute to solve this question, since their records do not show any Castanea and Juglans before 2500 cal. BP. They interpret these finds as a result of cultivation in the island in historical times. In addition, the absence of palynological investigations from Pleistocene sediments prevents us from speculating on a possible redeposition of pollen from older deposits. We would exclude a longdistance origin, especially for Juglans, whose pollen dispersal occurs over short distance despite its renowned anemophily (Carrión and Sánchez-Gómez, 1992).

Phylogeographical studies demonstrate that the post-glacial distribution of chestnut and walnut in Europe and in the Mediterranean regions started from multiple glacial refugia (Mattioni et al., 
2013; Pollegioni et al., 2017). However, due to both the scarcity of palaeobotanical knowledge and incomplete genetic sampling, as in the case of Corsica and Sardinia, there is still much uncertainty in detecting glacial refugia and drawing up robust biogeographical histories of cultivated trees (Médail et al., 2019).

In historical time, the OJCV record shows two major phases of tree cultivation. The first one, between $\sim 250$ BC and $\sim 150$ AD, reflects a widespread exploitation of olive resources during the Roman Period, also documented by archaeological evidence (Terral et al., 2004). The second increase, after $\sim 1450 \mathrm{AD}$, testifies to an intensification of Olea cultivation and a regional plantation of Castanea in the uplands. From 1548 until the $17^{\text {th }}$ century, the Genoese authority introduced the compulsory cultivation of chestnut, whose fingerprint in the Crovani record is represented by a peak of Castanea (Fig. 6) (Michon, 2011). The consequence of this decree was a large reorganization of the food production, economy, and socio-cultural systems, as shepherds slowly became chestnut growers and settled more permanently in mid-mountain villages. The chestnut culture fully developed during the $18^{\text {th }}$ and $19^{\text {th }}$ centuries, providing flour for daily meals, fodder for animals, and fruits for trade. By the end of the $19^{\text {th }}$ century, the development of local industries and the related outflow of rural population towards urban centres determined the collapse of the chestnut culture (Michon, 2011).

Human impact on the forest cover is recorded since $1000 \mathrm{BC}$ (Final Bronze Age), mostly by decreases in evergreen trees and shrubs staggered over time (Fig. 8), coupled with increases in both herbaceous vegetation and Cistus dominated low shrublands (Figs. 6 and 8). Considering the local modest farming activities during the last three millennia, this pattern may mostly reflect clearance practices of the Erica shrubland at a regional scale. This is consistent with the human-induced opening of the forests recorded in several other pollen sites of Corsica (Reille, 1992a; Revelles et al., 2019; Lestienne et al., 2020a), and in coastal sites of the central Mediterranean since 1000 cal. BC (Di Rita and Magri, 2012). According to Roberts et al. (2019), after $\sim 1000$ BC human activity became the dominant causation in determining landscape openings in the Mediterranean regions.

Despite the clear changes in land use recorded, human activities at Crovani did not completely transform the structure of the vegetation in terms of forest canopy, except for a temporary dramatic drop in the maquis vegetation between 950 and $1450 \mathrm{AD}$ (1000-500 cal. BP), for which a prominent anthropogenic causation cannot be ruled out. Pollen indicators of human activity are scarce in this period, but the reappearance of coprophilous fungi (Sporormiella) and the increase in Castanea and Olea, together with a slight increase in fire frequency, may reflect silvicultural practices aimed at felling shrublands to gain land available for both stock rearing and olive cultivation in the lowlands, as well as for chestnut cultivation in the uplands. A similar observation was advanced for the Saint-Florent area, where an important deforestation phase was coeval to the development of pastoral activities (Revelles et al., 2019). Between $\sim 1000$ and $\sim 500$ cal. BP, frequencies $>2 \%$ of Pseudoschizaea and Glomus support soil erosion and local deforestation (Figs. 7 and 10). This was also the time when several churches were locally built (Fig. 1A).

Human activities may also be tracked from the $\mathrm{Pb}$ isotope signature of the Crovani sediments. Sedimentary $\mathrm{Pb}$ data are aligned along a linear trend in a binary ${ }^{208} \mathrm{~Pb} /{ }^{206} \mathrm{~Pb}-{ }^{206} \mathrm{~Pb} /{ }^{207} \mathrm{~Pb}$ diagram (Fig. 5A and B). Such distribution indicates a mixing between two end-members, a natural end-member with higher isotope $\mathrm{Pb}$ ratios and a probable anthropogenic-derived endmember characterized by lower isotope ratios. (a) The first end-member has been defined by the average signature of 3 samples dated from the Final Neolithic period $(196-260 \mathrm{~cm})$. They are used to define the local detrital source with low isotopes ratios (i.e., ${ }^{208} \mathrm{~Pb} /{ }^{204} \mathrm{~Pb}=38.9584 \pm 0.0020$, ${ }^{207} \mathrm{~Pb} /{ }^{204} \mathrm{~Pb}={ }^{206} \mathrm{~Pb} /{ }^{204} \mathrm{~Pb} 15.6719 \pm 0.0008$ and ${ }^{206} \mathrm{~Pb} /{ }^{204} \mathrm{~Pb}=19.0775 \pm 0.0008$ ) (Table S1). This end-member represents the natural background end-member. The composition of the samples corresponding to the Iron Age, only defined by 2 measurements, is slightly different from the previous Bronze Age and Final Neolithic periods, with a position closer to the sample from the Roman representative average. The $\mathrm{Pb}$ isotope ratios of the sediments roughly decrease upwards from the natural background end-member. The oldest pre-Roman samples $(\mathrm{n}=19,93-260 \mathrm{~cm}$ ) are clustered with an average signature of $38.9667 \pm 0.0235$, $15.6716 \pm 0.0007$ and $19.0702 \pm 0.0008$ for ${ }^{208} \mathrm{~Pb} /{ }^{204} \mathrm{~Pb}$, ${ }^{207} \mathrm{~Pb} /{ }^{204} \mathrm{~Pb}$ and ${ }^{206} \mathrm{~Pb} /{ }^{204} \mathrm{~Pb}$, respectively.

(b) A shift towards lower $\mathrm{Pb}$ isotope ratios is marked for the Roman samples ( 53 and $73 \mathrm{~cm}$ ) and for the modern samples $(11-23 \mathrm{~cm})$. The first Roman shift may be related to some exploitation of $\mathrm{Pb}$ ores. The isotope composition of both regional $\mathrm{Pb}$-bearing ores and modern urban airborne particles (Bollhöfer and Rosman, 2001) are reported in order to confirm any anthropogenic contribution in the sediment $\mathrm{Pb}$ isotope composition. The isotope $\mathrm{Pb}$ ratios of the Roman and modern samples become closer and closer to the Corsican $\mathrm{Pb}$ minerals (Fig. 5). The analysed Pb-bearing minerals display close $\mathrm{Pb}$ isotope signatures, with an average composition of 1.1779 for ${ }^{206} \mathrm{~Pb} /{ }^{207} \mathrm{~Pb}$ and 2.0894 for ${ }^{208} \mathrm{~Pb} /{ }^{206} \mathrm{~Pb}$. The first decrease of the $\mathrm{Pb}$ isotopic ratio observed in the Roman Crovani sediments is in agreement with the historical exploitation of the $\mathrm{Pb}-\mathrm{Ag}$ ores from the Argentella during the Roman period (Gauthier, 2006). The linear trend defined by the modern samples does not point towards the modern urban airborne particles but rather towards the $\mathrm{Pb}$ signature of the Sardinian ores (Stos-Gale et al., 1995). In the Crovani sediments, Sardinia seems to be the most probable anthropogenic source of $\mathrm{Pb}$ among the main $\mathrm{Pb}$ mines exploited in the Mediterranean area, i.e. in Greece, Turkey, Italy and Spain since the Antiquity (see more details in Fagel et al., 2017). In the binary ${ }^{206} \mathrm{~Pb} /{ }^{207} \mathrm{~Pb}-{ }^{208} \mathrm{~Pb} /{ }^{206} \mathrm{~Pb}$ diagram, the Crovani samples define a linear trend that, if extrapolated, points to the representative average signature of Sardinian ores (Fig. 5 B).

\subsection{Effects of rapid climate changes on coastal tree-cover}

In the palaeobotanical narrative of Corsica, no clear tree-cover change has ever been attributed to a "Bond event" (Bond et al., 2001 ) (Fig. 8) or other RCC of global interest, such as the $4.2 \mathrm{ka}$ BP event (Bini et al., 2019), the Homeric minimum (2.8 ka BP) (Martin-Puertas et al., 2012) and the Little Ice Age (Trouet et al., 2009). These events caused major changes in forest cover in many sites of central and western Mediterranean regions, although with contrasting trends (Fletcher et al., 2013; Magny et al., 2013; Di Rita et al., 2018a).

The 4.2 cal. BP event, perceived in south-central Italy as an aridity crisis producing a forest decline, did not trigger a rapid response in the regional forest vegetation in Corsica and in the northern Apennines (Di Rita and Magri, 2019; Revelles et al., 2019; Di Rita et al., 2022). However, previous studies in Corsica have shown that the 4.2 event played an influence on geomorphological and sedimentological processes, due to increased storm and fluvial activities as recorded in several lagoon archives (Revelles et al., 
2019 and references therein). In our record from Crovani, rapid fluctuations of the forest cover are found, marked by maximum values of AP (92\%) at ca. 4450 cal. BP (Figs. 6 and 8). Between 4700 and 3500 cal. BP, a long-lasting increase in Fagus suggests permanent humid conditions during the Mid-to Late Holocene transition (Fig. 6), which are recorded also in other montane sites (Reille, 1975; Reille et al., 1999) and pollen sequences from coastal Corsica (Poher et al., 2017). The development of beech corresponds to relatively wet climatic conditions in central Italy, as revealed by lake level highstands at Lake Accesa ca. $160 \mathrm{~km}$ far from Crovani (Magny et al., 2013). Lake level highstands reflecting humid conditions are also recorded in northern Italy (cf. Lake Ledro: Magny et al., 2012), and in west-central Europe (Magny et al., 2013 and references therein).

The development of beech also corresponds to periods of increased storm activity in southern France (Sabatier et al., 2012) (Fig. 8). Although these periods were previously interpreted as a result of southward westerly winds bringing moisture to midlatitudes in Europe (Sabatier et al., 2012; Magny et al., 2013), they may also reflect an increase in the frequency of marine storms that are not directly interpretable as periods of regional increased precipitation (Azuara et al., 2020). An alkenone record from the Gulf of Lion suggests moisture increase in southern France since ca. 4200 cal. BP (Jalali et al., 2017; Azuara et al., 2020).

The general pattern of increased humidity in western Corsica contrasts with the drier conditions indicated by precipitation proxies from the speleothems of the Corchia and Renella caves in Tuscany (Zanchetta et al., 2016; Isola et al., 2019), and depicts a complex geographic expression of the 4.2 ka event (Bini et al., 2019; Di Rita and Magri, 2019; Di Rita et al., 2022).

The Homeric Minimum (2750-2550 cal. BP, Martin-Puertas et al., 2012) was associated to forest declines influenced by human impact and dryer climate conditions in many records of the south-central Mediterranean (Di Rita et al., 2018c). At Crovani, it corresponds to a modest peak in AP, possibly related to slightly wetter conditions. Relatively higher precipitations were recorded from lake-level highstands since 2800 cal. BP at Lake Accesa (Fig. 8), and from lake-level highstands and pollen evidence at Lake Ledro (Magny et al., 2012; Peyron et al., 2017). More humid climate conditions were also found in the western Mediterranean, possibly associated to the negative NAO index that characterizes this interval (Fletcher et al., 2013). This phase corresponds also to increased storm activity in the Gulf of Lion (Sabatier et al., 2012).

During the Little Ice Age, the record of Crovani shows a marked increase in Erica and Q. ilex maquis, accompanied by significant frequencies of cultivated trees related to orchards and conifer plantations (Figs. 6 and 8). The development of natural and cultivated woody taxa was probably favoured by relatively wet climate conditions, which were also recorded in both central and northern Italy from lake-level highstands (Magny et al., 2013), as well as in southern France from records of major flooding (Benito et al., 2015; Pichard et al., 2017), coinciding with a mostly negative NAO index (Franke et al., 2017) (Figs. 8 and 10). Climate reconstructions in Corsica are still fragmentary, however the few published studies indicate the occurrence of periods characterized by wet and cool conditions (Szymczak et al., 2012; Vella et al., 2014).

The archaeological and paleoenvironmental literature does not provide noticeable examples of rapid and dry climate events in Corsica. As previously discussed, the complex sedimentological pattern at $\sim 3250$. cal. BP (Fig. 4) might be related to an arid climate event observed around the same age in other palaeoenvironmental records. Relatively dry and warm climate conditions may also have contributed to the major forest decline recorded between 1000 and 500 cal. BP, limiting the resprout of the natural forest vegetation affected by felling activities. In the western Mediterranean, the dry and warm climate of the Medieval Climate Anomaly is usually associated to an overall positive NAO index (Trouet et al., 2009; Franke et al., 2017) (Fig. 8).

Sabatier et al. (2020) have found a strong relationship between the transport of Saharan dust conveyed to Corsica during the last $\sim 3000$ years and both total solar irradiance (TSI) and NAO activity. They have shown that the NAO was the main climatic forcing for centennial to decadal variations since $\sim 1070 \mathrm{AD}$, with an increase in Saharan dust input during positive NAO phases. Before $1070 \mathrm{AD}$, TSI was the main forcing factor, with increases in African dust input during low TSI phases.

We applied a REDFIT analysis to the total AP percentages to investigate the effects of the atmospheric circulation on the tree cover record from Crovani (Fig. 9). The prominent 230-year cycle found in our statistical elaboration by and large corresponds to the Suess-de Vries cycle of solar activity, which has been held responsible for environmental and atmospheric changes in several records around the world, including the Mediterranean (Castagnoli et al., 1992; Galloway et al., 2013; Di Rita, 2013; Degeai et al., 2014; Sabatier et al., 2020). The Suess-de Vries cycle is commonly identified as a conventional 210-year periodicity; however, an increasing number of studies demonstrates its non-stationary variability, which may have a range of $200-300$ years (Vecchio et al., 2017). Similarly, its expression in palaeoenvironment proxies shows a non-stationary periodicity (Galloway et al., 2013). A 230-year cycle was detected in direct proxies of solar magnetic activity, such as ${ }^{14} \mathrm{C}$ time series and naked-eye observations of sunspots (Ma and Vaquero, 2020).

The REDFIT analysis from Crovani shows also two periodicities of ca. 430 and 1000 years, respectively (Fig. 9). The first one corresponds to the ca. 430-years and 450-year cycles detected by Sabatier et al. (2020) in the records of Saharan dust in Corsica, as shown by both TSI and ITCZ, although the authors attribute a low significance to this cycle. A 440-year cycle (together with a 230year cycle) was found in $\delta^{13} \mathrm{C}$ records of speleothems from northern Iberia and was interpreted as the result of climate forcing mechanisms related to changes in solar irradiance and North Atlantic circulation patterns (Mártin-Chivelet et al., 2011). Periodicities of 400 -years were recognized in various palaeoclimate proxies from both marine (e.g., Bond et al., 2001) and lake records (e.g., Yu and Ito, 2002; Wu et al., 2009) of the Middle-Late Holocene.

The last periodicity we found at Crovani matches a prominent $\sim 1000$-year cycle of moisture supply reported in proxy records from the western Mediterranean, especially during the Early Holocene, which have been associated to solar activity (Debret et al., 2009; Fletcher et al., 2013; Jiménez Moreno et al., 2020 and references therein).

Overall, our results show that the forest oscillations at Crovani present a fundamental tempo of variability consistent with the atmospheric forcing held responsible for the transport of Saharan dust to Corsica. Although the relationship between solar activity and forest dynamics in Corsica is only sketched, our findings encourage future research in the central Mediterranean, interpreted in the light of the regional patterns of vegetation change.

\subsection{Coastal landscape evolution of the Crovani area}

Based on the cross combination of sedimentological, palynological and geochemical proxies, we propose a synthetic palaeogeographical reconstruction of the investigated area, even if additional cores would be necessary to evaluate in a comprehensive way both the morphological changes and the spatial evolution of the Crovani wetland since the Mid-Holocene. The bottom of the core records a detrital environment with a mixture of well-rounded 
pebbles and coarse material, ranging from sands to gravels. Unfortunately, this section of the core did not contain enough organic material for obtaining a radiocarbon age. Furthermore, facies identification was difficult due to the lack of fossil fauna. However, on the basis of the sedimentological information, two types of energy of deposition can be identified. The first is controlled by terrestrial dynamics being characterized by the finest particles (grey clays). The second is conversely controlled by coastal dynamics as indicated by the presence of well-rounded pebbles that are analogue in shape and petrography to the sediments which compose the modern coastal barrier. These data suggest that the continental dynamics likely prevailed during the first half of the Holocene. This was followed by a mid-Holocene marine transgression that reached its maximum $\sim 6500$ cal. BP, when the sealevel in Corsica was ca. 3.5-4 m below its present-day position (Vacchi et al., 2018). At that time, which broadly correspond to Middle to Late Neolithic, a marine incursion occurred in the Crovani coastal pond following a pattern that was also observed in other coastal lagoons in Corsica, such as Saint Florent (Revelles et al., 2019) and Del Sale (Curras et al., 2017). As a result, the pond turned into brackish conditions after $\sim 6100$ cal. BP, as confirmed by the presence of Spiniferites, which substantially indicates a connection with the sea (Figs. 6 and 10). However, probably due to the presence of Late Pleistocene alluvial formations and relict coastal deposits (former coastal barriers), the marine incursion inland was spatially limited. This could explain the lack of faunal assemblages typical of coastal lagoon made by ostracods, foraminifera and molluscs faunas. After $\sim 5100 \mathrm{cal}$. BP, during the Late to Final Neolithic characterized by the first occupation of the nearby site of Teghja di Linu, data show detrital input that suddenly modified the brackish conditions of the pond. However, our results indicate that neither a climatic event nor human impact resulted in deforestation associated with intense foothill erosion and sedimentary accumulation of coarse material, even if there was clear land use at that time (Fig. 10). A second phase of wetland development is well attested from the Final Neolithic to Middle/Late Bronze Age. Presence of salt intrusion is confirmed by both the vegetation composition and the geochemical analyses (presence of halite) but there is no clear evidence for a direct connection of the coastal pond to the sea (e.g., presence of faunal assemblages typical of coastal lagoons). A second detrital input is observed during the Late Bronze Age (Unit VII). The C/N Ratio exhibits the highest values for the entire sequence studied, thus indicating a terrestrial deposition of organic matter (see section 4.2.) (Fig. 4). This likely was a rapid event (not more than a century in duration) that could have caused the silting up of the wetland. Finally, the present-day landscape configuration was established starting from the Final Bronze Age (unit VIII) with very little morphological changes afterwards. Since $\sim 3200$ cal. BP, Crovani coastal pond has been a backshore freshwater body with probable aeolian input of salt, no permanent connection to the sea, and low sediment accumulation rate (Fig. 10).

\section{Conclusions}

The new multidisciplinary dataset obtained from northwest Corsica helps to reconstruct past environmental dynamics (Fig. 10) within an archaeological context, and to frame them into the wider scenario of the central Mediterranean landscape evolution. Our results contribute to the lively discussion on the vegetation response to rapid climate changes, as raising as new questions about planetary drivers of past atmospheric circulation and their possible influence on the forested ecosystems of this strategic region of the Mediterranean. In particular, the following conclusions can be drawn:
1) A dense Erica-dominated shrubland rich in many evergreen elements characterized the landscape from 6100 to $1000 \mathrm{cal}$. BP, being temporarily replaced by mixed woodlands dominated by Q. ilex between 2300 and 1900 cal. BP. A major opening of the landscape occurred only between $\sim 1000$ and 500 cal. BP, featured by a temporary decline in Erica-dominated tall shrublands, paralleled by an expansion of Cistus-dominated low shrublands and followed by the recovery of the tall maquis formations.

2) Fires played a prominent role in the development and maintenance of the Erica-dominated shrublands, especially during the Middle Holocene (from 5900 to 5200 cal. BP), when frequent and intense wild and anthropogenic fires boosted the sprout of Erica species. Differently from other sites in Corsica and Sardinia, at Crovani fires did not affect Q. ilex, whose development cannot be univocally explained in the region and may be influenced by a long-lasting ecological legacy. The general decrease of fires after $\sim 3300$ cal. BP may reflect a combination of decreased human activity and climate unsuitable for fires.

3) The Crovani wetland has been little influenced by marine incursions over the last six millennia, as indicated by sedimentological data, pollen and NPPs. Moderate brackish conditions occurred only from the Late Neolithic to part of the Bronze Age, while during the last three millennia general freshwater conditions prevailed. The sequential development of dinoflagellates, Ruppia, and ferns appears to reflect a hydrosere succession, whose evolution is strictly related to the infilling of the lake. After $3300 \mathrm{cal}$. BP, this ecological process was influenced by a sudden deposition of continental organic-rich sediments, following rapid deforestation and runoff of regional extension, coeval to an arid climate event occurred around 3200 cal. BP.

4) Evidence for human activity is present throughout the pollen record, with important differences through time. Between $\sim 6000$ and $\sim 5200$ cal. BP, a continuous curve of cereal-type pollen testifies to the earliest cultivations in this area. Farming activities are also confirmed by the presence of disturbed meadows for livestock rearing, indicated by coprophilous fungi and pollen indicators of plants frequently living in Mediterranean pasturelands. Starting around $3300 \mathrm{cal}$. BP, indicators of cereal cultivation and stock rearing practices become sparse, and evidence for human activity comes from cultivated trees, especially after ca. 2000 cal. BP and even more after $\sim 500$ cal. BP. The former increase reflects olive exploitation during the Roman Period, the latter points to both olive cultivation in lowland areas and chestnut culture in the uplands. A clear forest degradation dates back to the last three millennia, with a dramatic opening of the landscape only from 1000 to 500 cal. BP, related to human activity in the medieval times and Genoese domination.

5) The spectral analysis applied to total AP revealed a $~ 230$-year cycle, in the bandwidth of the Suess-de Vries cycle, and other cyclicities attributed to the magnetic activity of the Sun, recognized also in other climate proxies from the Mediterranean. This suggests that the atmospheric modifications of solar activity and North Atlantic Oscillation had some influence on the tree cover fluctuations in Corsica. However, known rapid climate changes, such as the $4.2 \mathrm{ka} \mathrm{BP}$ event, the Homeric minimum, and the Little Ice Age, did not determine at Crovani extensive forest declines as they did in sites of the south-central Mediterranean. In contrast, in northwestern Corsica these phases correspond to a forest development consistent with the humid phases detected in southern France and northern Italy. The high-resolution record from Crovani is an important piece of information to define the spatial pattern of vegetation response to the 
atmospheric arrangements produced by rapid climate changes over the Mediterranean Basin during the Holocene.

\section{Authors' contributions}

All authors have materially participated in the research project and article preparation, as follows. Conceptualization: FDR, MG, NF, and MV. Sediment collection: MG, JS and LM. Methodology: FDR, MG, NF, and MV. Formal analyses: FDR, MG, NF, MV, FW, DD, and SR. Data collection: FDR, MG, NF, MV, FW, DD, JS, LM, and SR. Results interpretation: FDR, MG, NF, and MV. Writing original draft: FDR, MG, NF, and MV. Contribution in interpreting results and writing the paper: FW, DD, JS, LM, and SR. Funding acquisition: MG.

\section{Declaration of competing interest}

The authors declare that they have no known competing financial interests or personal relationships that could have appeared to influence the work reported in this paper.

\section{Acknowledgements}

This article is a contribution of the PCR "Approche géoarchéologique des paysages de Corse à l'Holocène, entre mer et intérieur des terres «Tra Mare è Monti » programme, funded by the DRAC Corsica and directed by Matthieu Ghilardi. It is also part of the MISTRALS-PALEOMEX programme of CNRS, France (INEE-INSU scientific departments) and was funded by the ARCHEOMED workshop (Dir. Laurent Lespez). This research was also supported by Sapienza University of Rome, Italy (grant numbers RM11715C820D1E6F, RM1181641COCB0C7, and RM120172AE4E11D6). The authors are grateful to the Conservatoire du Littoral (branch of Corsica) and its Director, Michel Muracciole, for delivering the work permits. We thank Donatella Magri for her precious suggestions and two anonymous reviewers for helpful comments.

\section{Appendix A. Supplementary data}

Supplementary data to this article can be found online at https://doi.org/10.1016/j.quascirev.2022.107372.

\section{References}

Azuara, J., Sabatier, P., Lebreton, V., Jalali, B., Sicre, M.-A., Dezileau, L., Bassetti, M.-A., Frigola, J., Combourieu-Nebout, N., 2020. Mid- to Late-Holocene Mediterranean climate variability: contribution of multi-proxy and multi-sequence comparison using wavelet spectral analysis in the northwestern Mediterranean basin. Earth Sci. Rev. 208, 103232. https://doi.org/10.1016/j.earscirev.2020.103232.

Beffa, G., Pedrotta, T., Colombaroli, D., Henne, P.D., van Leeuwen, J.F.N., Süsstrunk, P., Kaltenrieder, P., Adolf, C., Vogel, H., Pasta, S., Anselmetti, F.S., Gobet, E., Tinner, W., 2016. Vegetation and fire history of coastal north-eastern Sardinia (Italy) under changing Holocene climates and land use. Veg. Hist. Archaeobotany 25, 271-289.

Bellotti, P., Calderoni, G., Di Rita, F., D'Orefice, M., D'Amico, C., Esu, D., Magri, D., Preite Martinez, M., Tortora, P., Valeri, P., 2011. The Tiber river delta plain (central Italy): coastal evolution and implications for the ancient Roman Ostia settlement. Holocene 21, 1105-1116.

Benito, G., Macklin, M.G., Zielhofer, C., Jones, A.F., Machado, M.J., 2015. Holocene flooding and climate change in the Mediterranean. Catena 130,13-33.

Bengtsson, L., Enell, M., 1986. Chemical analysis. In: Berglund, B.E. (Ed.), Handbook of Holocene Palaeoecology and Palaeohydrology. John Wiley \& Sons Ldt., Chichester, pp. 423-451.

Bennett, K., 2009. "psimpoll" and "Pscomb": CPrograms for Analysing Pollen Data and Plotting Pollen Diagrams (Version 4.27). Available online from Queen's University Quaternary Geology program at URL. http://www.chrono.qub.ac.uk/ psimpoll/psimpoll.html.

Berger, J.F., Brochier, J.L., Vital, J., Delhon, C., Thiebault, S., 2007. Nouveau regard sur la dynamique des paysages et l'occupation humaine à l'Âge du bronze en moyenne vallée du Rhône. In: Mordant, C., Richard, H., Magny, M. (Eds.), Environnements et cultures à l'âge du Bronze en Europe occidentale. Actes du 129e colloque du CTHS, Besançon, avril 2004, Editions du CTHS, vol. 21. Documents Préhistoriques, pp. 260-283.

Beug, H., 2004. Leitfaden der Pollenbestimmung fiir Mitteleuropaund angrenzende Gebiete. Verlag Dr. Friederich Pfeil, München.

Bini, M., Zanchetta, G., Perşoiu, A., Cartier, R., Català, A., Cacho, I., Dean, J.R., Di Rita, F., Drysdale, R.N., Finnè, M., Isola, I., Jalali, B., Lirer, F., Magri, D., Masi, A., Marks, L., Mercuri, A.M., Peyron, O., Sadori, L., Sicre, M.-A., Welc, F., Zielhofer, C., Brisset, E., 2019. The 4.2 ka BP Event in the Mediterranean region: an overview. Clim. Past 15, 555-577.

Birks, H.J.B., Line, J.M., 1992. The use of rarefaction analysis for estimating palynological richness from Quaternary pollen-analytical data. Holocene 2, 1-10.

Blaauw, M., Christen, J.A., 2011. Flexible paleoclimate age-depth models using an autoregressive gamma process. Bayesian Anal. 6, 457-474.

Bollhöfer, A., Rosman, K.J.R., 2001. Isotopic source signature for atmospheric lead: the Northern Hemisphere. Geochem. Cosmochim. Acta 65, 1727-1740.

Bond, G., Kromer, B., Beer, J., Muscheler, R., Evans, M.N., Showers, W., Hoffmann, S., Lotti-Bond, R., Hajdas, I., Bonani, G., 2001. Persistent solar influence on North Atlantic climate during the holocene. Science 294, 2130-2136.

Bottema, S., 1975. The interpretation of pollen spectra from prehistoric settlements (with special attention to Liguliflorae). Palaeohistoria 17, 17-35.

Carcaillet, C., Barakat, H.N., Panaïotis, C., Loisel, R., 1997. Fire and late-Holocene expansion of Quercus ilex and Pinus pinaster on Corsica. J. Veg. Sci. 8, 85-94.

Carrión, J.S., 2002. Patterns and processes of Late Quaternary environmental change in a montane region of southwestern Europe. Quat. Sci. Rev. 21, 2047-2066.

Carrión, J.S., Sánchez-Gómez, P., 1992. Palynological data in support of the survival of walnut (Juglans regia L.) in the western Mediterranean area during last glacial times. J. Biogeogr. 19, 623-630.

Carrión, J.S., Parra, I., Navarro, C., Munuera, M., 2000. Past distribution and ecology of the cork oak (Quercus suber) in the Iberian Peninsula: a pollen-analytical approach. Divers. Distrib. 6, 29-44.

Castagnoli, G.C., Bonino, G., Serio, M., Sonnett, C.P., 1992. Common spectral features in the 5500-year record of total carbonate in sea sediments and radiocarbon in tree rings. Radiocarbon 34, 798-805.

Caudullo, G., Tinner, W., de Rigo, D., 2016. Picea abies in Europe: distribution, habitat, usage and threats. In: San-Miguel-Ayanz, J., de Rigo, D., Caudullo, G., Houston Durrant, T., Mauri, A. (Eds.), European Atlas of Forest Tree Species. Publications Office of the European Union, e012300. Luxembourg.

Cesari, J., Pêche-Quilichini, K., 2015. L'âge du Bronze corse. L'émergence d'une élite guerrière, in Leandri F., Istria D. (coord.), Corse, richesses archéologiques de la Préhistoire à l'époque moderne. Dossiers Archéol. 370, 24-29.

Clark, R.L., 1982. Point count estimation of charcoal in pollen preparations and thin sections of sediments. Pollen Spores 24, 523-535.

Colombaroli, D., Tinner, W., Leeuwen, J., van Noti, R., Vescovi, E., Vanniere, B., Magny, M., Schmidt, R., Bugmann, H., 2009. Response of broadleaved evergreen Mediterranean forest vegetation to fire disturbance during the Holocene: insights from the peri-Adriatic region. J. Biogeogr. 36, 314-326.

Cook, H.E., Johnson, P.D., Matti, J.C., Zemmels, I., 1975. Methods of sample preparation and X-ray diffraction analysis in X-ray mineralogy laboratory. In: Kaneps, A.G. (Ed.), Init. Repts DSDP XXVIII. Print. Office, Washington DC, pp. 997-1007.

Cugny, C., Mazier, F., Galop, D., 2010. Modern and fossil non-pollen palynomorphs from the Basque mountains (western Pyrenees, France): the use of coprophilous fungi to reconstruct pastoral activity. Veg. Hist. Archaeobotany 19, 391-408.

Currás, A., Ghilardi, M., Peche-Quilichini, K., Fagel, N., Vacchi, M., Delanghe, D., Contreras, D., Vella, C., Ottaviani, J.C., 2017. Reconstructing past landscapes of the eastern plain of Corsica (NW Mediterranean) during the last 6000 years based on molluscan, sedimentological and palynological analyses. J. Archaeol. Sci.: Report 12, 755-769.

D'Anna, A., Marchesi, H., Tramoni, P., Gilabert, C., Demouche, F., 2001. Renaghju (Sartène, Corse-du-Sud), un habitat de plein-air néolithique ancien en Corse. Bull. Soc. Prehist. Fr. 98, 431-444.

Dean Jr., W.E., 1974. Determination of carbonate and organic matter in calcareous sediments and sedimentary rocks by loss on ignition: comparison with other methods. J. Sediment. Petrol. 44, 242-248.

Debret, M., Sebag, D., Crosta, X., Massei, N., Petit, J.R., Chapron, E., BoutRoumazeilles, V., 2009. Evidence from wavelet analysis for a mid-Holocene transition in global climate forcing. Quat. Sci. Rev. 28, 2675-2688.

Degeai, J.P., Devillers, B., Dezileau, L., Oueslati, H., Bony, G., 2015. Major storm periods and climate forcing in the western mediterranean during the late holocene. Quat. Sci. Rev. 129, 37-56.

Desprat, S., Combourieu-Nebout, N., Essallami, L., Sicre, M.A., Dormoy, I., Peyron, O., Siani, G., Bout Roumazeilles, V., Turon, J.L., 2013. Deglacial and Holocene vegetation and climatic changes in the southern Central Mediterranean from a direct land-sea correlation. Clim. Past 9, 767-787.

de Vernal, A., Eynaud, F., Henry, M., Limoges, A., Londeix, L., Matthiessen, J., Marret, F., Pospelova, V., Radi, T., Rochon, A., Van Nieuwenhove, N., Zaragosi, S., 2018. Distribution and (palaeo)ecological affinities of the main Spiniferites taxa in the mid-high latitudes of the Northern Hemisphere. Palynology 42, $182-202$.

Di Rita, F., 2013. A possible solar pacemaker for Holocene fluctuations of a saltmarsh in southern Italy. Quater. Bar Int. 288, 239-248.

Di Rita, F., Magri, D., 2012. An overview of the Holocene vegetation history from the central Mediterranean coasts. J. Mediterr. Earth Sci. 4, 35-52.

Di Rita, F., Magri, D., 2019. The 4.2 ka event in the vegetation record of the central 
Mediterranean. Clim. Past 15, 237-251.

Di Rita, F., Melis, R.T., 2013. The cultural landscape near the ancient city of Tharros (central West Sardinia): vegetation changes and human impact. J. Archaeol. Sci. 40, 4271-4282.

Di Rita, F., Fletcher, W.J., Aranbarri, J., Margaritelli, G., Lirer, F., Magri, D., 2018a. Holocene forest dynamics in central and western Mediterranean: periodicity, spatio-temporal patterns and climate influence. Sci. Rep. 8, 8929.

Di Rita, F., Molisso, F., Sacchi, M., 2018b. Late Holocene environmental dynamics, vegetation history, human impact, and climate change in the ancient Literna Palus (Lago Patria; Campania, Italy). Rev. Palaeobot. Palynol. 258, 48-61.

Di Rita, F., Lirer, F., Bonomo, S., Cascella, A., Ferraro, L., Florindo, F., Insinga, D.D., Lurcock, P.C., Margaritelli, G., Petrosino, P., Rettori, R., Vallefuoco, M., Magri, D., 2018c. Late Holocene forest dynamics in the Gulf of Gaeta (central Mediterranean) in relation to NAO variability and human impact. Quat. Sci. Rev. 179, 137-152.

Di Rita, F., Michelangeli, F., Celant, A., Magri, D., 2022. Sign-switching ecological changes in the Mediterranean basin at 4.2 ka BP. Global Planet. Chang. 208, 103713.

Fagel, N., Lechenault, M., Fontaine, N., Pleuger, E., Otten, J., Allan, M., Ghilardi, M., Mattielli, N., Goiran, J.-P., 2017. Record of human activities in the Pb isotopes signatures of coastal sediments from the Roman archaeological site of Cala Francense, Cape Corsica (France). J. Archaeol. Sci.: Rep. 12, 770-781.

Fletcher, W.J., Debret, M., Goñi, M.F.S., 2013. Mid-Holocene emergence of a lowfrequency millennial oscillation in western Mediterranean climate: implications for past dynamics of the North Atlantic atmospheric westerlies. Holocene 23, 153-166.

Florenzano, A., Marignani, M., Rosati, L., Fascetti, S., Mercuri, A.M., 2015. Are Cichorieae an indicator of open habitats and pastoralism in current and past vegetation studies? Plant Biosyst. 149, 154-165.

Franke, J.G., Werner, J.P., Donner, R.V., 2017. Reconstructing Late Holocene North Atlantic atmospheric circulation changes using functional paleoclimate networks. Clim. Past 13, 1593-1608.

Galloway, J.M., Wigston, A., Patterson, R.T., Swindles, G.T., Reinhardt, E., Roe, H.M., 2013. Climate change and decadal to centennial-scale periodicities recorded in a late Holocene NE Pacific marine record: examining the role of solar forcing. Palaeogeogr. Palaeoclimatol. Palaeoecol. 386, 669-689.

Galop, D., Carozza, L., Marembert, F., Bal, M.C., 2007. Activités agropastorales et climat durant l'Âge du Bronze dans les Pyrénées : l'état de la question à la lumière des données environnementales et archéologiques. In: Mordant, C., Richard, H., Magny, M. (Eds.), Environnements et cultures à l'âge du Bronze en Europe occidentale. Actes du 129e colloque du CTHS, Besançon, avril 2004, Editions du CTHS, vol. 21. Documents Préhistoriques, pp. 107-119.

Gauthier, A., 2006. Des roches, des paysages et des hommes. Géologie de la Corse, Ajaccio. Edition Albiana, France, p. 276.

Galer, S.J.G., Abouchami, W., 1998. Practical application of lead triple spiking for correction of instrumental mass discrimination. 8th Goldschmidt Conf. Mineral. Mag. 62A, 491-492.

Gelorini, V., Verbeken, A., van Geel, B., Cocquyt, C., Verschuren, D., 2011. Modern non-pollen palynomorphs from East African lake sediments. Rev. Palaeobot. Palynol. 164, 143-173.

Ghilardi, M., 2020. Lagunes et marais littoraux de Corse. De la Préhistoire à nos jours. Collec. Orma: la Corse archéologie. Ed. ARAC 5, 105.

Ghilardi, M., 2021. Geoarchaeology: where geosciences meet the humanities to reconstruct past human-environment interactions. An Application to the Coastal Areas of the Largest Mediterranean Islands. Appl. Sci. 11, 4480. https:// doi.org/10.3390/app11104480.

Ghilardi, M., Istria, D., Currás, A., Vacchi, M., Contreras, D., Vella, C., Dussouillez, P., Crest, Y., Colleu, M., Guiter, F., Delanghe, D., 2017a. Reconstructing the landscape evolution and the human occupation of the lower Sagone river (western Corsica, France) from the bronze age to the medieval period. In: Ghilardi, M., Lespez, L. (Eds.), Geoarchaeology of the Mediterranean Islands. J. Archaeol. Sci.: Reports, vol. 12, pp. 741-754.

Ghilardi, M., Delanghe, D., Demory, F., Leandri, F., Pêche-Quilichini, K., Vacchi, M., Vella, M.A., Rossi, V., Robresco, S., 2017b. Enregistrements d'événements extrêmes et évolution des paysages dans les basses vallées fluviales du Taravo et du Sagone (Corse occidentale, France) au cours de l'âge du Bronze moyen à final: une perspective géoarchéologique. Géomorphol. Relief Process. Environ. $23,15-35$.

Grimm, E.C., 1987. CONISS: a FORTRAN 77 program for stratigraphically constrained cluster analysis by the method of incremental sum of squares. Comput. Geosci. $13,13-35$.

Hammer, Ø., Harper, D.A.T., Ryan, P.D., 2001. PAST: paleontological Statistics software package for education and data analysis. Palaeontol. Electron. 4, 9.

Havinga, A.J., 1984. A 20-year experimental investigation into the differential corrosion susceptibility of pollen and spores in various soil types. Pollen Spores 26, 541-558.

Henry, A.G. (Ed.), 2020. Handbook for the Analysis of Micro-particles in Archaeological Samples. Springer international publishing.

Isola, I., Zanchetta, G., Drysdale, R.N., Regattieri, E., Bini, M., Bajo, P., Hellstrom, J.C., Baneschi, I., Lionello, P., Woodhead, J., 2019. The 4.2 ka event in the Central Mediterranean: new data from a Corchia speleothem (Apuan Alps, Central Italy). Clim. Past 15, 135-151.

Jalali, B., Sicre, M.-A., Kallel, N., Azuara, J., Combourieu-Nebout, N., Bassetti, M.-A., Klein, V., 2017. High-resolution Holocene climate and hydrological variability from two major Mediterranean deltas (Nile and Rhone). Holocene 27 (8),
$1158-1168$.

Jeanmonod, D., Schlüssel, A., 2006. Notes and contributions on Corsican flora, XXI. Candollea 61, 93-134.

Jiménez-Moreno, G., Anderson, R.S., Ramos-Román, M.J., Camuera, J., MesaFernández, J.M., García-Alix, A., Jiménez-Espejo, F.J., Carrión, J.S., LópezAvilés, A., 2020. The Holocene Cedrus pollen record from Sierra Nevada (S Spain), a proxy for climate change in N Africa. Quat. Sci. Rev. 242, 106468.

Kantrud, H.A., 1991. Wigeongrass (Ruppia Maritima L.): A Literature Review, vol. 10. U.S. Fish and Wildlife Service, Fish and Wildlife Research, p. 58.

Kouli, K., Brinkhuis, H., Dale, B., 2001. Spiniferites cruciformis: a fresh water dinoflagellate cyst? Rev. Palaeobot. Palynol. 113, 273-286.

Lestienne, M., Jouffroy-Bapicot, I., Leyssenne, D., Sabatier, P., Debret, M., Albertini, P.J., Colombaroli, D., Didier, J., Hély, C., Vannière, B., 2020a. Fires and human activities as key factors in the high diversity of Corsican vegetation. Holocene 30, 244-257.

Lestienne, M., Hely, C., Curt, T., Jouffroy-Bapicot, I., Vannière, B., 2020b. Combining the monthly drought code and paleoecological data to assess holocene climate impact on mediterranean fire regime. Fire 3 (2), 8.

Leleu, F., 2021. Calenzana-Les mines de l'Argentella. Prospection thématique (2018). ADLFI. Archéologie de la France - Informations [Online], Corse, Online since 08 January 2021, connection on 14 December 2021. http://journals. openedition.org/adlfi/50226.

Leys, B., Carcaillet, C., Dezileau, L., Ali, A.A., Bradshaw, R.H., 2013. A comparison of charcoal measurements for reconstruction of Mediterranean paleo-fire frequency in the mountains of Corsica. Quat. Res. 79, 337-349.

Leys, B., Finsinger, W., Carcaillet, C., 2014. Historical range of fire frequency is not the Achilles' heel of the Corsican black pine ecosystem. J. Ecol. 102, 381-395.

Lugliè, C., 2018. Your path led trough the sea... the emergence of Neolithic in Sardinia and Corsica. Quat. Int. 470, 285-300.

Ma, L., Vaquero, J.M., 2020. New evidence of the Suess/de Vries cycle existing in historical naked-eye observations of sunspots. Open Astron. 29, 28-31.

Magny, M., Joannin, S., Galop, D., Vannière, B., Haas, J.N., Bassetti, M., Bellintani, P., Scandolari, R., Desmet, M., 2012. Holocene palaeohydrological changes in the northern Mediterranean borderlands as reflected by the lake-level record of Lake Ledro, northeastern Italy. Quat. Res. 77, 382-396.

Magny, M., Combourieu-Nebout, N., de Beaulieu, J.L., Bout-Roumazeilles, V., Colombaroli, D., Desprat, S., Francke, A., Joannin, S., Ortu, E., Peyron, O., Revel, M., Sadori, L., Siani, G., Sicre, M.A., Samartin, S., Simonneau, A., Tinner, W., Vannière, B., Wagner, B., Zanchetta, G., Anselmetti, F., Brugiapaglia, E., Chapron, E., Debret, M., Desmet, M., Didier, J., Essallami, L., Galop, D., Gilli, A., Haas, J.N., Kallel, N., Millet, L., Stock, A., Turon, J.L., Wirth, S., 2013. North-south palaeohydrological contrasts in the central Mediterranean during the Holocene: tentative synthesis and working hypotheses. Clim. Past 9, 2043-2071.

Magri, D., Di Rita, F., 2015. Archaeopalynological preparation techniques. In: Yeung, E.C.T., Stasolla, C., Sumner, M.J., Huang, B.Q. (Eds.), Plant Microtechniques and Protocols. Springer International Publishing, Cham, pp. 495-506.

Magri, D., Celant, A., Di Rita, F., 2019. The vanished Alnus-dominated forests along the Tyrrhenian coast. Catena 182, 104136.

Martín-Chivelet, J., Muñoz-García, M.B., Edwards, R.L., Turrero, M.J., Ortega, A.I., 2011. Land surface temperature changes in Northern Iberia since $4000 \mathrm{yr}$ BP, based on $\delta^{13} \mathrm{C}$ of speleothems. Global Planet. Change 77, 1-12.

Martìn-Puertas, C., Matthes, K., Brauer, A., Muscheler, R., Hansen, F., Petrick, C., Aldahan, A., Possnert, G., van Geel, B., 2012. Regional atmospheric circulation shifts induced by a grand solar minimum. Nat. Geosci. 5, 397-401.

Mattioni, C., Martin, M.A., Pollegioni, P., Cherubini, M., Villani, F., 2013. Microsatellite markers reveal a strong geographical structure in European populations of Castanea sativa (Fagaceae): evidence for multiple glacial refugia. Am. J. Bot. 100, 951-961.

Médail, F., Monnet, A.-C., Pavon, D., Nikolic, T., Dimopoulos, P., Bacchetta, G., Arroyo, J., Barina, Z., Albassatneh, M.C., Domina, G., Fady, B., Matevski, V., Mifsud, S., Leriche, A., 2019. What is a tree in the Mediterranean Basin hotspot? A critical analysis. Forest Ecosyst. 6, 17.

Melis, R.T., Depalmas, A., Di Rita, F., Montis, F., Vacchi, M., 2017. Mid to late holocene environmental changes along the coast of western Sardinia (Mediterranean Sea). Global Planet. Change 155, 29-41.

Melis, R.T., Di Rita, F., French, C., Marriner, N., Montis, F., Serreli, G., Sulas, F., Vacchi, M., 2018. 8000 years of coastal changes on a western Mediterranean island: a multiproxy approach from the Posada plain of Sardinia. Mar. Geol. 403, 93-108.

Michon, G., 2011. Revisiting the resilience of chestnut forests in Corsica: from socialecological systems theory to political ecology. Ecol. Soc. 16, 5.

Moore, D.M., Reynolds Jr., R.C., 1997. X-Ray Diffraction and the Identification and Analysis of Clay Minerals. Oxford New York. Oxford Univ. Press, p. 378.

Pantaleón-Cano, J., Yll, E.I., Pérez-Obiol, R., Roure, J.M., 2003. Palynological evidence for vegetational history in semi-arid areas of the western Mediterranean (Almería, Spain). Holocene 13, 109-119.

Peche-Quilichini, K., 2011. Les monuments turriformes de l'Age du bronze en Corse: tentative de caractérisation spatiale et chronologique sur fond d'historiographie. In: Garcia, Dominique (Ed.), L'Age du bronze en Méditerranée. Recherches récentes. Errance, Paris, pp. 155-170.

Pedrotta, T., Gobet, E., Schwörer, C., Beffa, G., Butz, C., Henne, P.D., MoralesMolino, C., Pasta, S., van Leeuwen, J.F.N., Vogel, H., Zwimpfer, E., Anselmetti, F.S., Grosjean, M., Tinner, W., 2021. 8,000 years of climate, vegetation, fire and landuse dynamics in the thermo-mediterranean vegetation belt of northern Sardinia (Italy). Veg. Hist. Archaeobotany 30, 789-813. 
Peyron, O., Combourieu-Nebout, N., Brayshaw, D., Goring, S., Andrieu-Ponel, V., Desprat, S., Fletcher, W., Gambin, B., Ioakim, C., Joannin, S., Kotthoff, U., Kouli, K., Montade, V., Pross, J., Sadori, L., Magny, M., 2017. Precipitation changes in the Mediterranean basin during the Holocene from terrestrial and marine pollen records: a model-data comparison. Clim. Past 13, 249-265.

Pichard, G., Arnaud-Fassetta, G., Moron, V., Roucaute, E., 2017. Hydro-climatology of the Lower Rhône Valley: historical flood reconstruction (AD 1300-2000) based on documentary and instrumental sources. Hydrol. Sci. J. 62, 1772-1795.

Poher, Y., Ponel, P., Médail, F., Andrieu-Ponel, V., Guiter, F., 2017. Holocene environmental history of a small Mediterranean island in response to sea-level changes, climate and human impact. Palaeogeogr. Palaeoecol. 465, 247-263.

Pollegioni, P., Woeste, K., Chiocchini, F., Del Lungo, S., Ciolfi, M., Olimpieri, I., Tortolano, V., Clark, J., Hemery, G.E., Mapelli, S., Malvolti, M.E., 2017. Rethinking the history of common walnut (Juglans regia L.) in Europe: its origins and human interactions. PLoS One 12, e0172541.

Regattieri, E., Zanchetta, G., Drysdale, R.N., Isola, I., Hellstrom, J.C., Dallai, L., 2014. Lateglacial to holocene trace element record ( $\mathrm{Ba}, \mathrm{Mg}, \mathrm{Sr}$ ) from Corchia Cave (Apuan Alps, central Italy): paleoenvironmental implications. J. Quat. Sci. 29, 381-392.

Reille, M., 1975. Contribution pollen analytique à l'histoire tardiglaciaire et holocène de la végétation de la montagne corse. Thèse des sciences Aix-Marseille III.

Reille, M., 1984. Origine de la végétation actuelle de la Corse sud-orientale; analyse pollinique de cinq marais côtiers. Pollen et Spores 26, 43-60.

Reille, M., 1991. Les données de l'analyse pollinique. Rapport fouille programme Grotte du Norte di Tuda, Olmeta di Tuda, pp. 149-160. Rapport fouille programme Grotte du Norte di Tuda. Olmeta di Tuda.

Reille, M., 1992a. New pollen-analytical researches in Corsica: the problem of Quercus ilex L. and Erica arborea L., the origin of Pinus halepensis Miller forests. New Phytol. 122, 359-378.

Reille, M., 1992b. Pollen et spores d'Afrique du nord. Laboratoire de Bot. Hist. et Palynologie, Marseille.

Reille, M.J., Gamisans, V., Andrieu-Ponel, V., De Balieu, J.-L., 1999. The Holocene at Lac de Creno, Corsica, France: a key site for the whole island. New Phytol. 141, 291-307.

Reimer, P.J., Austin, W.E., Bard, E., Bayliss, A., Blackwell, P.G., Ramsey, C.B., Butzin, M., Cheng, H., Edwards, R.L., Friedrich, M., Grootes, P.M., et al., 2020. The IntCal20 northern hemisphere radiocarbon age calibration curve (0-55 cal kBP). Radiocarbon 62, 725-757.

Revelles, J., Ghilardi, M., Vacchi, M., Rossi, V., Currás, A., López-Bultò, O., Brkojewitsch, G., 2019. Coastal landscape evolution of Corsica: palaeoenvironments, vegetation history and human impacts since the Early Neolithic period. Quat. Sci. Rev. 225, 105993.

Revelles, J., Ghilardi, M., 2021. 49. Saint florent (north Corsica, France). Grana 60, $158-160$.

Roberts, C.N., Woodbridge, J., Palmisano, A., Bevan, A., Fyfe, R., Shennan, S., 2019. Mediterranean landscape change during the Holocene: synthesis, comparison and regional trends in population, land cover and climate. Holocene 29 (5), 923-937.

British plant communities. In: Rodwell, J.S. (Ed.), 2000. Maritime Communities and Vegetation of Open Habitats, vol. 5. Cambridge University Press, Cambridge.

Sabatier, P., Dezileau, L., Colin, C., Briqueu, L., Bouchette, F., Martinez, P., Siani, G., Raynal, O., Von Grafenstein, U., 2012. 7000 years of paleostorm activity in the NW Mediterranean Sea in response to Holocene climate events. Quat. Res. 77, $1-11$.

Sabatier, P., Nicolle, M., Piot, C., Colin, C., Debret, M., Swingedouw, D., Perrette, Y., Bellingery, M.-C., Chazeau, B., Develle, A.-L., Leblanc, M., Skonieczny, C., Copard, Y., Reyss, J.-L., Malet, E., Jouffroy-Bapicot, I., Kelner, M., Poulenard, J., Didier, J., Arnaud, F., Vannière, B., 2020. Past African dust inputs in the western Mediterranean area controlled by the complex interaction between the Intertropical Convergence Zone, the North Atlantic Oscillation, and total solar irradiance. Clim. Past 16, 283-298.

Schulz, M., Mudelsee, M., 2002. REDFIT: estimating red-noise spectra directly from unevenly spaced paleoclimatic time series. Comput. Geosci. 28, 421-426.

Scott, L., 1992. Environmental implications and origin of microscopic Pseudoschizaea Thiergart and Frantz ex R Potonié emend. in sediments. J. Biogeogr. 19, 349-354.

Szymczak, S., Joachimski, M.M., Bräuning, A., Hetzer, T., Kuhlemann, J., 2012. A 560 yr summer temperature reconstruction for the Western Mediterranean basin based on stable carbon isotopes from Pinus nigra ssp. laricio (Corsica/France). Clim. Past 8, 1737-1749.

Sicurani, J., 2008. Étude technologique et typologique du matériel lithique taillé néolithique trouvé en place sur quelques sites majeurs du Nord-Ouest (Balagne) de la Corse. Thèse de Doctorat Univ. Corse 714.

Sicurani, J., Martinet, L., 2019. Teghja di Linu: un site de plein air du début du iiie millénaire av. J.-C. (Luzzipeu, Haute-Corse). In Sicurani J. (dir.), L'habitat pré- et protohistorique/L'alloghju prestoricu è protostoricu, acte du Ier colloque de
Calvi (Calvi, 28-30 avril 2017). ARPPC, pp. 45-70.

Stax, R., Stein, R., 1993. Long-term changes in the accumulation of organic carbon in neogene sediments, Ontong Java plateau. Proc. Ocean Drill. Program Sci. Res. $130,573-584$

Stos-Gale, Z., Gale, N.H., Houghton, J., Speakman, R., 1995. Lead Isotope Data from the Isotrace Laboratory, vol. 37. Archaeometry data base 1, ores from the Western Mediterranean. Archaeometry, Oxford, pp. 407-415.

Terral, J.-F., Alonso, N., Buxó i Capdevila, R., Chatti, N., Fabre, L., Fiorentino, G., Marinval, P., Pérez Jordá, G., Pradat, B., Rovira, N., Alibert, P., 2004. Historical biogeography of olive domestication (Olea europaea L.) as revealed by geometrical morphometry applied to biological and archaeological material. J. Biogeogr. 31, 63-77.

Trouet, V., Esper, J., Graham, N.E., Baker, A., Scourse, J.D., Frank, D.C., 2009. Persistent positive North Atlantic Oscillation mode dominated the medieval climate anomaly. Science 324 (5923), 78-80.

Vacchi, M., Ghilardi, M., Spada, G., Currás, A., Robresco, S., 2017. New insights into the sea-level evolution in Corsica (NW Mediterranean) since the late Neolithic. J. Archaeol. Sci.: Rep. 12, 782-793.

Vacchi, M., Joyse, K.M., Kopp, R.E., Marriner, N., Kaniewski, D., Rovere, A., 2021. Climate pacing of millennial sea-level change variability in the central and western Mediterranean. Nat. Commun. 12 (1), 1-9.

Vacchi, M., Marriner, N., Morhange, C., Spada, G., Fontana, A., Rovere, A., 2016 Multiproxy assessment of Holocene relative sea-level changes in the western Mediterranean:sea-level variability and improvements in the definition of the isostatic signal. Earth Sci. Rev. 155, 172-197.

Vacchi, M., Ghilardi, M., Melis, R.T., Spada, G., Giaime, M., Marriner, N., Lorscheid, T., Morhange, C., Burjachs, F., Rovere, A., 2018. New relative sea-level insights into the isostatic history of the Western Mediterranean. Quat. Sci. Rev. 201, 396-408.

van Geel, B., 2001. Non-pollen palynomorphs. In: Smol, J.P., Birks, H.J.B., Last, W.M. (Eds.), Tracking Environmental Change Using Lake Sediments. Terrestrial, Algal and Silicaceous Indicators, vol. 3. Kluwer, Dordrecht, pp. 99-119.

Vecchio, A., Lepreti, F., Laurenza, M., Alberti, T., Carbone, V., 2017. Connection between solar activity cycles and grand minima generation. Astron. Astrophys. 599, A58.

Vella, M.A., Tomas, É., Thury-Bouvet, G., Muller, S., 2014. Nouvelles données sur le petit âge de glace en Corse: apports de l'analyse croisée des informations géomorphologique, palynologique et archéologique de la piève de Santo Pietro (désert de l'Agriate, Corse). Méditerranée. Rev. Géogr. Méditerr./J. Mediterr. Geogr. 122, 99-111.

Vella, M.A., Andrieu-Ponel, V., Cesari, J., Leandri, F., Pêche-Quilichini, K., Reille, M. Poher, Y., Demory, F., Delanghe, D., Ghilardi, M., Ottaviani-Spella, M.D., 2019. Early impact of agropastoral activities and climate on the littoral landscape of Corsica since mid-Holocene. PLoS One 14 (12), e0226358.

Vigne, J.D., 1984. Premières données sur les débuts de l'élevage du Mouton, de la Chèvre et du Porc dans le sud de la Corse (France). In: Clutton-Brock, J., et Grigson, C. (Eds.), In: Animals and Archaeology, 3-Early Herders and Their Flocks. Proceedings 4th Int. Council for Archaeozoology, Londres, 1982, vol. 202. Archaeopress, BAR International Series, Oxford, pp. 47-65.

Vigne, J.D., 1987. L'exploitation des ressources alimentaires en Corse du VIIe au IVe millénaire. In: Guilaine, J., Courtin, J., RoudilJ, .L., et al. (Eds.), Premières communautés paysannes en Méditerranée occidentale. CNRS éditions, pp. 193-199.

Weis, D., Kieffer, B., Maerschalk, C., Barling, J., de Jong, J., Williams, G.A., Hanano, D., Pretorius, W., Mattielli, N., Scoates, J.S., Goolaerts, A., Friedman, R.M., Mahoney, J.B., 2006. High-precision isotopic characterization of USGS reference materials by TIMSand MC-ICP-MS. Geochem. Geophys. Geosyst. 7, Q08006.

Weiss, M.-C., 2010. Au Vle millénaire avant notre ère. A Petra à L'île Rousse : campagnes de fouilles (2003-2006), p. 247. Ajaccio, Albiana.

Wu, J., Yu, Z., Zeng, Z., Wang, N., 2009. Possible solar forcing of 400-year wet-dry climate cycles in northwestern China. Climatic Change 96, 473-482.

Yu, Z.C., Ito, E., 2002. The 400-year wet-dry climate cycle in Interior North America and its solar connection. In: West, G.J., Blomquist, N.L. (Eds.), Proceedings of the Nineteenth Annual Pacific Climate Workshop. Technical Report, vol. 71, pp. 159-163.

Zanchetta, G., Regattieri, E., Isola, I., Drysdale, R., Bini, M., Baneschi, I., Hellstrom, J., 2016. The so-called "4.2 event" in the central Mediterranean and its climatic teleconnections. Alp. Mediterr. Quat. 29, 5-17.

Zonneveld, K.A.F., Marret, F., Versteegh, G.J.M., Bonnet, S., Bouimetarhan, I., Crouch, E., de Vernal, A., Elshanawany, R., Edwards, L., Esper, O., Forke, S., Grøsfjeld, K., Henry, M., Holzwarth, U., Kielt, J.-F., Kim, S.-Y., Ladouceur, S., Ledu, D., Chen, L., Limoges, A., Londeix, L., Lu, S.-H., Mahmoud, M.S., Marino, G., Matsouka, K., Matthiessen, J., Mildenhal, D.C., Mudie, P., Neil, H.L., Pospelova, V., Qi, Y., Radi, T., Richerol, T., Rochon, A., Sangiorgi, F., Solignac, S., Turon, J.-L., Verleye, T., Wang, Y., Wang, Z., Young, M., 2013. Atlas of modern dinoflagellate cyst distribution based on 2405 datapoints. Rev. Palaeobot. Palynol. 191, 1-197. 